\title{
FX Forward Market in Hungary: General Characteristics and Impact of the COVID Crisis*
}

\author{
Anna Boldizsár - Zalán Kocsis - Zsuzsa Nagy-Kékesi - Gábor Sztanó
}

Our study investigates the basic characteristics, structure and time trends of the Hungarian FX forward market. We demonstrate that, in addition to non-financial firms active in international trade, mutual funds have become key actors in this market. Hedging and speculative motives - based on expectations of EURHUF stability - can be identified in the trading of both sectors. Non-financials are however more sensitive to exchange rate changes than financial actors. Crises, such as the global financial turbulence experienced in March 2020 due to the spread of the coronavirus, are characterised by a decline in speculative trading. During the depreciation of the forint together with regional currencies at the end of March, nonfinancial firms did not increase their net long HUF forward positions, while mutual funds increased their short HUF positions due to precautionary considerations, the depreciation of international assets and liquidity shocks (redemption of mutual fund shares, increasing margin call funding requirements).

Journal of Economic Literature (JEL) codes: C32, D84, F31, G32

Keywords: FX forward market, exchange rate exposure, mutual funds, time-varying parameter model, COVID crisis

\section{Introduction}

The subject matter of this study is the Hungarian FX forward market. The paper discusses the structure and trends of this market, and the behavioural patterns and motivations of its participants.

\footnotetext{
* The papers in this issue contain the views of the authors which are not necessarily the same as the official views of the Magyar Nemzeti Bank.

\begin{abstract}
Anna Boldizsár is an Economic Analyst at the Magyar Nemzeti Bank. Email: boldizsara@mnb.hu Zalán Kocsis is a Senior Economist at the Magyar Nemzeti Bank.Email: kocsisz@mnb.hu

Zsuzsa Nagy-Kékesi is a Senior Economist at the Magyar Nemzeti Bank. Email: kekesizsu@mnb.hu

Gábor Sztanó is an Analyst at the Magyar Nemzeti Bank. Email: sztanog@mnb.hu
\end{abstract}

We would like to thank Csaba Balogh and Péter Koroknai for their useful comments in preparing the study and the preliminary analyses, and to Attila Kürtösi, Edina Némethné Székely and Béla Brinzik for querying the data used in our study, and for the expert support related to the data. We would like to thank the Treasury / ALM colleagues of all domestic banks contacted in the April interviews for willingly contributing their knowledge and experience, which helped a better understanding of the market.

The Hungarian manuscript was received on 17 June 2020.

DOI: http://doi.org/10.33893/FER.19.3.551 
In a number of respects, the FX forward market is an important area for Hungarian economic and financial actors, as well as the central bank. It plays a role in domestic international trade because many exporters and importers use FX forwards to mitigate their currency risk. Reducing risk may foster international trade and thus economic activity. Domestic mutual funds use the forward market primarily for hedging purposes, mainly to mitigate the currency risk of the FX asset portfolio. In addition, as discussed in the existing literature, the carry trade (long positions taken in currencies with higher interest rates) and more generally currency speculation, i.e. trading involving positions to exploit exchange rate expectations, also motivate the transactions of domestic actors. The latter, speculative trading motive, is mainly characteristic in the case of retail customers and exporters. Hungarian domestic actors typically bet on the mean reversion (i.e. the stability) of the EURHUF exchange rate.

For the central bank, the FX forward market is important because this market has historically provided support for the forint spot market and strengthened its liquidity. Global shocks to the domestic currency, which typically spill over to the domestic market as a result of purchases and sales by foreign actors, are dampened by the reverse-direction FX forward trading of domestic actors, leading to a smaller change in the exchange rate compared to what would be the case without such activity by domestic actors.

One novel aspect of our analysis is to provide insight into an aspect of the financial market turbulence related to the coronavirus epidemic at the end of March 2020, during which the forward market showed a different pattern than before: it acted to increase the volatility of the forint exchange rate instead of dampening it. We explore the background of this development based on bank interviews and the data available to the Central Bank of Hungary (Magyar Nemzeti Bank).

\subsection{Related literature}

Much of our analysis is descriptive in nature with an aim to explain the basic characteristics and structure of the market for FX forwards in Hungary. The study thereby continues the tradition represented by several comprehensive studies of the MNB, which describe Hungarian financial markets - and more specifically the FX derivatives market (Csávás - Gereben 2005; Csávás et al. 2006; Gereben et al. 2006; Csávás - Szabó 2010; Páles et al. 2010; Banai et al. 2013; Kocsis et al. 2013). Our study is most closely related to Csávás et al. (2006), who investigated the FX forward market in more detail. Their study revealed key features of the Hungarian forward market back in 2006, including the reasons behind the trading activity of the non-financial sector. The current study builds strongly on these insights and examines the direction in which these features have changed over the past nearly 15 years. 
Descriptive analyses of similar vein are mainly published by the Bank for International Settlements (BIS) about international, global financial markets. To relate the Hungarian market to the global market, we use the data of the BIS Triennial Survey (BIS 2019a) and rely on descriptive BIS studies that investigate these data and the background of global FX market processes (Borio et al. 2017; BIS 2019b). Borio et al. (2017) argue that the global economy is fundamentally influenced by off-balance-sheet financing obtained through derivative items: they calculate that in this way USD 10.7 trillion of debt is hidden in balance sheets. Traditionally, forward transactions have played a key role in managing the "natural" FX exposure of non-financial firms active in international trade, as exporters hedge their FX revenues, while importers hedge their FX expenditures partly using these financial instruments. However, according to BIS studies (Borio et al. 2017; Patel - Xia 2019), inter-dealer transactions between financial corporations and banks currently account for a significantly larger volume compared to the derivative trading of non-financials, and recently transactions related to financial investments contributed most to the growth of the FX derivatives market.

Our study is related to the extensive literature that discusses the FX market activity of the non-financial corporate sector, mainly their foreign currency borrowing and taking FX forward positions. One segment of this literature quantifies natural FX exposures due to international trade, assesses how and to what extent non-financial companies hedge these exposures and investigates what firm characteristics explain differences regarding hedging activity. A large-scale meta-analysis of the literature by Geyer-Klingeberg et al. (2019) shows that the results are highly dependent on the chosen method and the (international and time) sample (175 studies are used in the meta-analysis which attests the breadth of this literature).

There are some general conclusions nonetheless: larger and internationally more integrated corporations with higher natural FX exposures (i.e. multinational firms) appear to be more active and more involved in using FX hedging tools (e.g. GuayKothari 2003; Kim - Sung 2005; Geyer-Klingeberg et al. 2019). Bodnár (2009) arrives at a similar result for the Hungarian non-financial corporate sector. International comparisons confirm that there are significant differences between countries both due to differences in the overall development of financial markets (Pramborg 2005) and due to the fact that firms in dollarized countries, which are more vulnerable to crises, have a larger need for hedging (Gatopoulos - Loubergé 2013).

One central question related to non-financial firms' participation in the FX forward market (and FX funding markets) is what reasons, in addition to the hedging motive, could explain transactions. In addition to hedging the natural currency mismatch in cash flows, the early risk management literature discusses aspects of managerial 
risks and income (e.g. Smith - Stulz 1985), and transactions with speculative purposes are also elaborated (Géczy et al. 2007). In the literature, the speculative motivation for trading is usually related to the empirical failure of uncovered interest rate parity, the forward premium anomaly (Fama 1984; Yu 2013; Barroso - Santa-Clara 2015; Jurek 2015), which promises profits for carry trade strategies, i.e. holding long FX positions of high-interest-rate currencies funded in low-interestrate currencies. There may also be additional supply-side motivations (resulting from banks hedging their own FX exposure) behind the FX market purchases of non-financial firms.

With regard to the Hungarian data, several studies confirm the existence of a hedging motive for non-financial firms' forward market participation using various methods (Csávás et al. 2006; Bodnár 2006, 2009; Harasztosi - Kátay 2020), though the granular corporate level data of Harasztosi - Kátay (2020) links only a small part of the transactions to the hedging motive. Harasztosi - Kátay (2020) also finds a small role for exploiting the interest rate differential, which contradicts the results of Bodnár $(2006,2009)$ based on questionnaire-based surveys. Interestingly, Kim - Chance (2018) finds that firms tend to report a larger role of hedging motives in questionnaire-based surveys compared to their true FX market activity, which is better characterised by speculative motives. Csávás et al. (2006) reveals that the trading pattern of non-financial firms is consistent with expectations of the stability of the forint exchange rate. Vonnák (2018) and Harasztosi - Kátay (2020) highlight the significant impact of banks' supply-side factors in FX positions of corporates.

At the microeconomic level, hedging FX exposures versus speculative activity that is less related to the balance sheet position contributes to firm value (Allayannis et al. 2012) and to credit risk, while at the macroeconomic level it relates to issues of financial stability. Systematically unhedged FX debt of corporates can lead to financial stability problems and can have noticeable negative effects on real economic activity as well during a crisis (Endrész et al. 2012; Endrész - Harasztosi 2014; Endrész 2020).

Finally, the literature on the risk management of financial market actors is also relevant to our study. This literature examines empirical correlations between different asset classes / exchange rates to evaluate risk management strategies, and thus the use of $\mathrm{FX}$ derivatives, in the case of investors with international portfolios (e.g. Massa et al. 2016; Mun 2016). 


\subsection{Sources of data}

We rely on two data sets for the Hungarian FX forward market, both based on the reporting of domestic banks prescribed by the central bank. In the D01 report, available since 1999, the MNB requests domestic credit institutions to report daily FX market transactions. This data set allows for the tracking of the FX spot, forward and futures, options and swap transactions of domestic banks. For each transaction, banks report the purchase and sale currency and volume of the transaction (based on this implied pricing can be calculated), the date of the contract, the maturity date (where applicable), counterparty characteristics (domestic / foreign residence, bank / non-bank, for financial actors usually also a unique identifier), as well as other transaction details (whether the transaction is related to stock exchange / OTC trading, whether it includes margining, whether the spot transaction is delivery of a derivative transaction) and pricing parameters (option premium for options, interest rates in cross-currency interest rate swaps). One important advantage of the D01 report is the historical depth of the time series, its daily frequency, and the rapid reporting of transactions that allows daily monitoring of the market (transactions are reported the day after the contract).

Our other source of data originates from the monthly M05 report, available since 2017, which is also provided by credit institutions to the central bank and includes reporting on the stock of $\mathrm{FX}$ and interest rate derivatives outstanding at the end of the month. In the case of FX forwards, banks report the nominal value and market value of the portfolio and the volume of trading (number of transactions) for the given period for each currency pair (both short and long directions) in large maturity buckets (within-year, 1-2 years and longer than 2 years). One of the main advantages of the M05 data source for our study is that banks report their FX forward market portfolios by sectors of counterparties, and from this information we can cautiously deduce the forward stocks and net exposures of domestic financial and non-financial actors (within that households and corporations separately). The counterparty codes and residence code in the D01 report also help in identifying counterparties, but there are many missing or technical identifiers here, and therefore the $\mathrm{M} 05$ report captures the sectoral composition much more accurately.

In addition to these two sources of data, we collected anecdotal information about the forward market. We interviewed Treasury / ALM colleagues of eight major domestic banks in early April. These eight banks cover 85 per cent of the outstanding FX forward portfolio of the Hungarian banking system.

Other data sources used for this study are the international FX market statistics collected by the BIS and the F07 data reports of the MNB. The latter has been 
available since 2009 and includes monthly information on key balance sheet items of mutual funds (broken down to HUF, EUR and other foreign currency categories).

\subsection{Structure of the study}

The next section includes a general description of the FX forward market. First, it identifies the sub-market of the global FX market on which the study focuses, FX forwards with one leg in HUF, where one of the counterparties is a Hungarian bank. The section then deals with several descriptive characteristics of this segment (currency denomination, maturity, transaction volume). The third section presents the structure of the domestic market, discussing the main participation motives of the three key actors (domestic banks, non-financial firms involved in international trade, mutual funds). The fourth section presents time-varying estimates of the exchange rate sensitivity of forward positions. The fifth section analyses the developments related to the coronavirus crisis this spring. The sixth section summarises the main findings.

\section{General characteristics of the FX forward market}

\subsection{Global FX market}

According to the BIS Triennial survey, ${ }^{1}$ global FX market turnover showed a rising trend over the past twenty years, with few smaller setbacks (BIS 2019a). Schrimpf - Sushko (2019) links the temporary decrease in 2016 to the abolition of the Swiss franc cap in January 2015, which shook the global FX market, and to adjustment to new regulatory standards. Interestingly, in terms of dynamics (and total turnover), currency swaps and not spot transactions represent the most important transaction type. However, in addition to currency swaps, all FX sub-markets - thus the spot, forward and options markets - also expanded significantly. The BIS data show that the financial market customer base of banks still plays a major role among market participants, accounting for almost half of the turnover by 2019, while the activity of non-financial corporations was below 10 per cent.

Forward transactions, as the focus of our analysis, account for roughly 18 per cent of global FX market turnover. The share of forward transactions increased significantly compared to the 11-12 per cent typical in the 2000s. However, currency swaps (including both FX swaps with maturity within one year and currency interest rate swaps with maturity over one year) were slightly pushed to the background in the first half of 2010, before their share rose again in the 2019 survey to around 50 per cent within the total FX market turnover (Figure 1).

\footnotetext{
${ }^{1}$ The BIS Triennial Survey, the BIS's comprehensive survey is the most obvious source on global FX market trends. The BIS conducts the survey under the coordination of central banks, with some 1,300 financial institutions in 53 countries contributing to the latest release (BIS 2019a). The Triennial Survey provides data on portfolios and turnover (on the average daily turnover in April in the year of publication).
} 

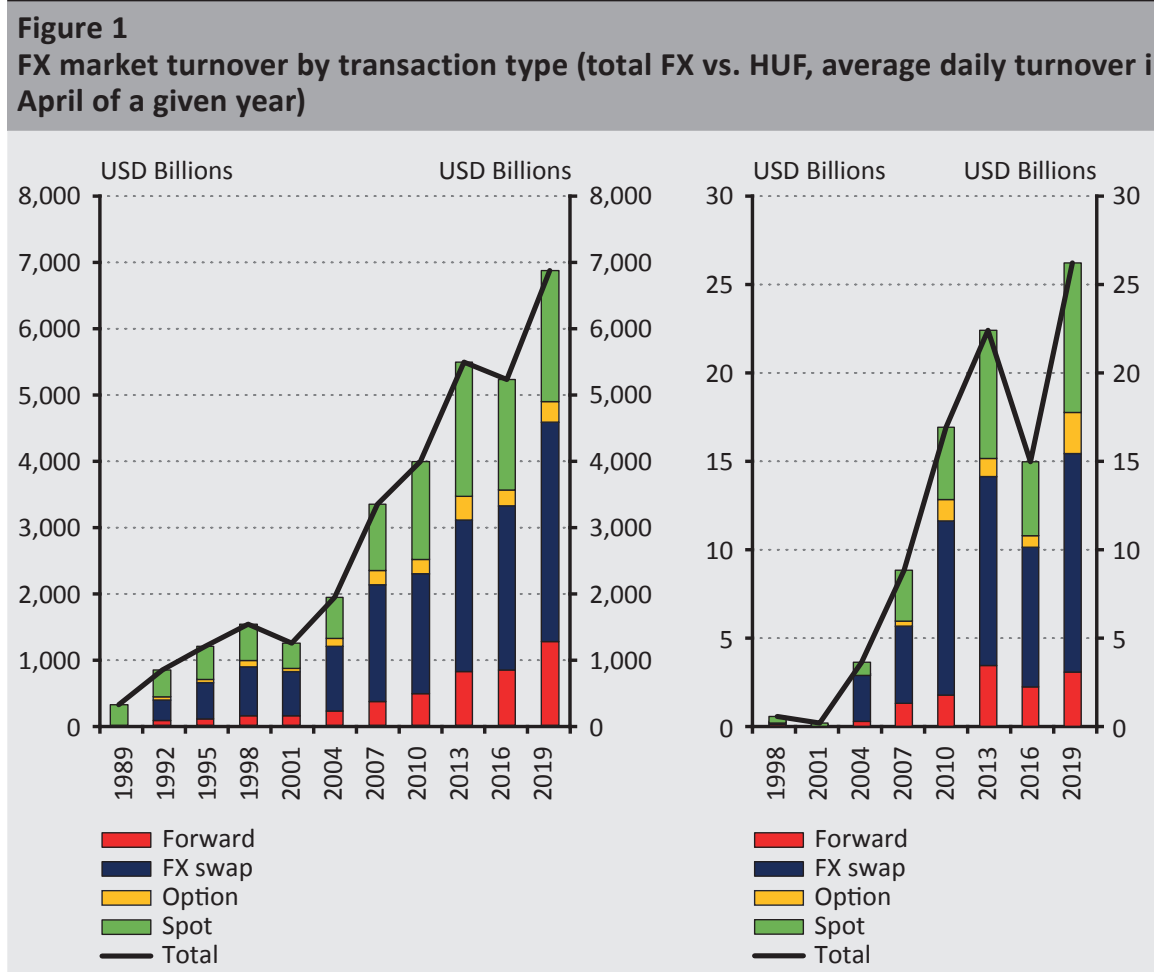

Note: The left panel shows the average daily volumes of all globally traded currencies in April, whereas the right panel shows the average daily volumes of globally traded transactions vis-à-vis the HUF in April.

Source: Edited based on BIS (2019a)

The HUF market accounts for a small share of the global FX market. Barely half of one per cent of global FX transactions have the HUF as the purchase or sale denomination. The same is true for the global vs. HUF relation in the case of forward transactions.

Prior to full convertibility of forint in 2001, international HUF turnover was insignificant compared to current volumes, and since the beginning of the 2000s, there has been a sharp increase in particular in currency swaps. Similar to the data aggregated by all currencies, HUF trading also came to a temporary halt in 2016. Among the types of transactions, FX swaps continue to account for the largest share of the volume, i.e. stable at half of the total market turnover. On the other hand, the share of forwards within HUF transactions decreased: compared to 15 per cent in 2013 and 2016, it was recently at 11 per cent. $^{2}$

\footnotetext{
${ }^{2}$ In practice, forward positions can be significantly larger than those observed in forward transactions, given that combining FX swaps and spot transactions result in a (synthetic) forward position.
} 
In both the MNB and BIS data sets, most HUF transactions were concluded against the euro. However, on the basis of BIS data, the share of the euro is nearly onethird, while according to MNB data, HUF transactions were trades against the euro in nearly two-thirds of transactions. This is probably due to HUF transactions between non-residents taking place at a higher proportion versus the USD than in the case of transactions reported by domestic banks, which are typically executed with or on behalf of counterparties with EUR involvement. According to BIS, of the approximately USD 3 billion daily HUF forward turnover, approx. 1 billion is transacted against the euro and 2 billion against other currencies. However, nonconsolidated data suggest that - in addition to non-euro transactions - forint transactions against the US dollar are significant (Figure 2).

\section{Figure 2 \\ Distribution of HUF transactions by type of transactions and currencies transacted against the forint}

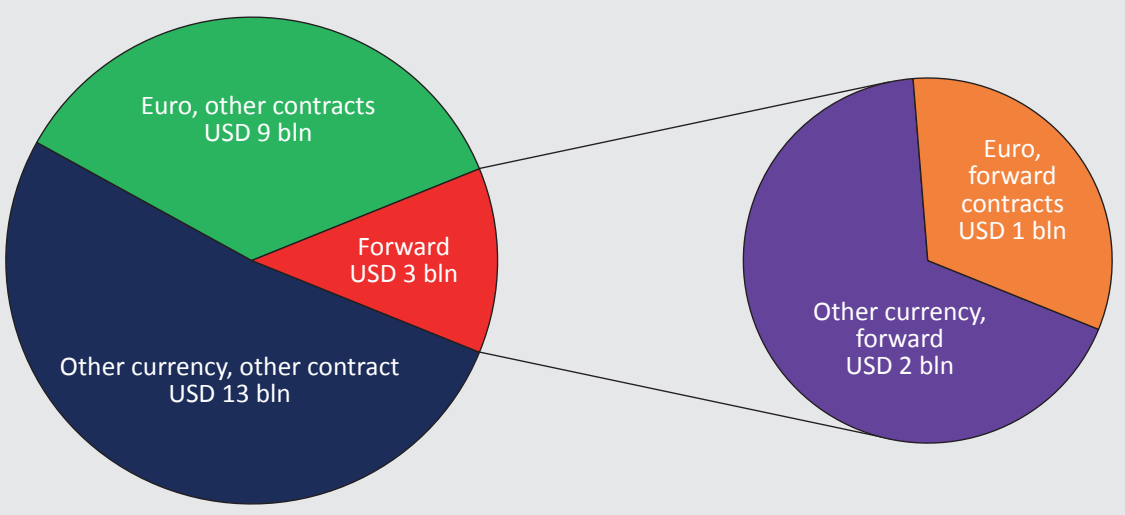

Note: The chart on the left shows the distribution of the turnover of global HUF transactions by forwards and other transactions (spot, swap, option). The chart on the right further breaks down global HUF forward transactions by currencies.

Source: Edited based on BIS (2019a)

According to BIS data, HUF transactions are mostly concluded in the United Kingdom and the United States (BIS 2019a). Based on the residence of market participants reporting HUF transactions, there has been no major change in recent years: most HUF transactions continue to be concluded outside Hungary. Interestingly, the share of transactions concluded in the United States decreased significantly in the case of forward transactions in particular between 2016 and 2019, and some Asian financial centres also reported HUF transactions in 2019 (Hong Kong, Singapore, China). At the same time, outside the United States and the United Kingdom, HUF transactions are mostly concluded in Europe, typically in countries that have direct exposure in the Hungarian financial markets. According to the survey, the share of transactions concluded in Hungary is nearly 8 per cent, taking into account all FX transactions (Figure 3). 


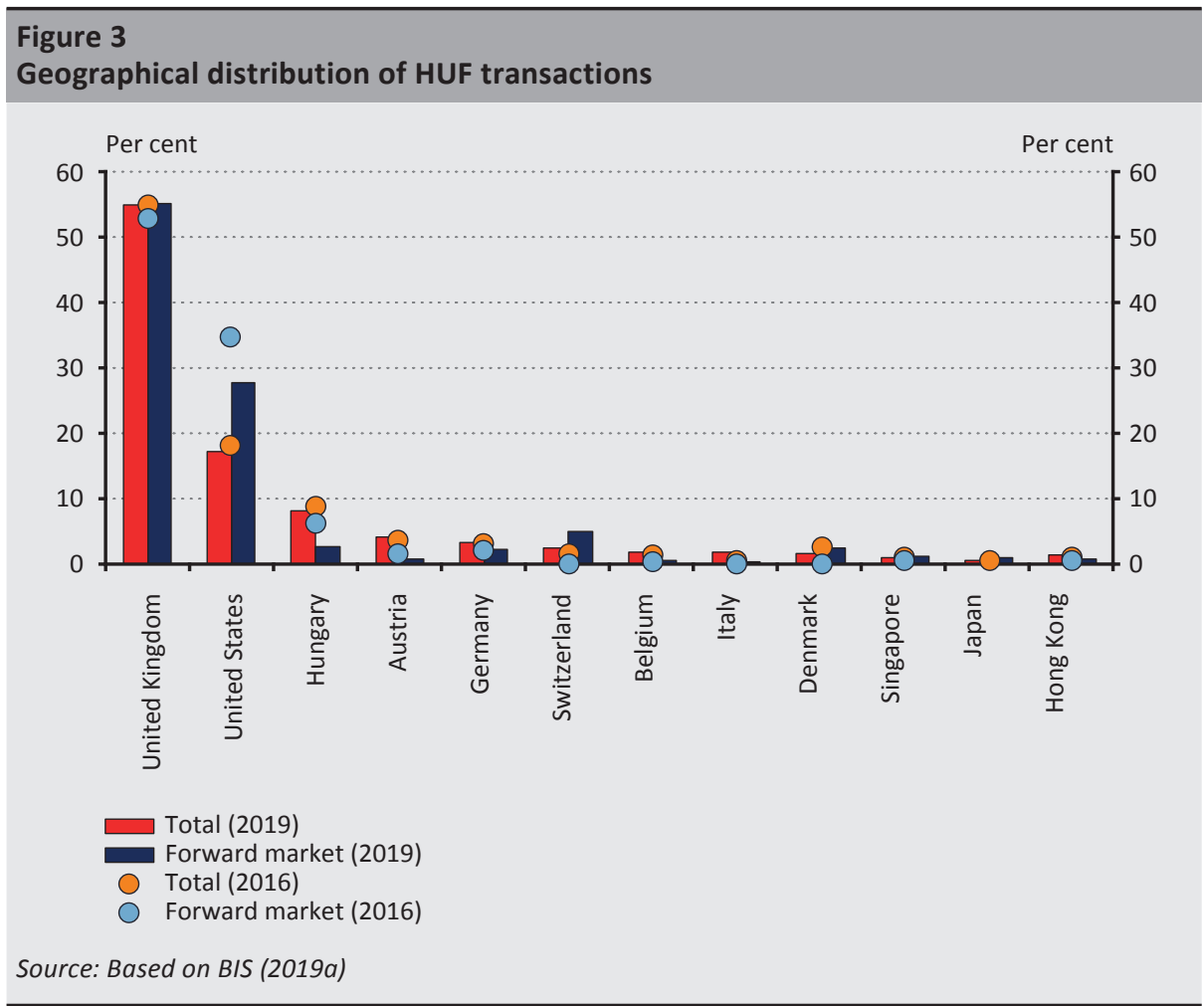

\subsection{Characteristics of the Hungarian FX market and forward market}

The segment of the Hungarian forint / FX market which is observable through data available from the reporting of domestic banks to the MNB is much smaller than the global HUF market presented above. The total FX market turnover reported by banks amounts to approximately HUF 900 billion per day, of which currency swaps and spot transactions account for the largest part. The average daily turnover of the Hungarian forward market is HUF 65 billion, which is largely consistent with the data collected by BIS: the turnover that can be traced by MNB data may account for 6-8 per cent of the total global forint market.

Based on the transactions reported by Hungarian banks, market participants are most active in the short segment of the forward market: almost three-quarters of the average daily transaction covers transactions of a maximum 3-month maturity, while the share of transactions longer than one year is barely one and a half per cent. This is also in line with BIS data: in the international market, the proportion 
of transactions shorter than 3 months was 85 per cent, and only about 5 per cent of transactions were longer than 6 months.

Transaction volumes are also higher for shorter maturities. The 1-3 month segment includes the highest average volumes by transactions. The skewness of the distribution of transaction volumes is positive: the average is increased by a small number of large transactions, and typical transactions are significantly smaller than the average. The median transaction volume was around HUF 30-60 million, compared to the average of HUF 150-300 million (Table 1).

\begin{tabular}{|c|c|c|c|c|c|}
\hline \multicolumn{6}{|c|}{$\begin{array}{l}\text { Table } 1 \\
\text { Daily average transaction volume and turnover }\end{array}$} \\
\hline & \multicolumn{5}{|c|}{ Maturity } \\
\hline & $<1$ month & $\begin{array}{l}\text { 1-3 } \\
\text { months }\end{array}$ & $\begin{array}{l}\text { 3-6 } \\
\text { months }\end{array}$ & $\begin{array}{l}\text { 6-12 } \\
\text { months }\end{array}$ & $\begin{array}{l}>12 \\
\text { months }\end{array}$ \\
\hline $\begin{array}{l}\text { Average daily volume traded } \\
\text { (HUF billion) }\end{array}$ & 30.0 & 20.9 & 8.1 & 5.6 & 1.1 \\
\hline \multicolumn{6}{|c|}{ Transaction volume (HUF million) } \\
\hline average & 269.1 & 286.7 & 235.8 & 240.0 & 144.1 \\
\hline perc $10 \%$ & 6.1 & 10.0 & 9.4 & 7.9 & 4.2 \\
\hline perc $20 \%$ & 10.2 & 18.5 & 16.2 & 15.6 & 8.1 \\
\hline perc $30 \%$ & 17.9 & 30.5 & 25.7 & 19.5 & 16.1 \\
\hline perc $40 \%$ & 29.1 & 34.1 & 31.9 & 31.3 & 22.4 \\
\hline median & 34.4 & 59.2 & 45.8 & 34.9 & 32.1 \\
\hline perc $60 \%$ & 61.9 & 85.8 & 65.5 & 60.4 & 39.0 \\
\hline perc $70 \%$ & 98.1 & 136.8 & 106.7 & 85.3 & 60.1 \\
\hline perc $80 \%$ & 186.0 & 235.4 & 166.9 & 156.0 & 82.8 \\
\hline perc 90\% & 428.0 & 545.0 & 391.4 & 336.1 & 162.4 \\
\hline \multicolumn{6}{|c|}{ Note: January 2017 - May 2020 sample } \\
\hline
\end{tabular}

Based on the development of the transactions' maturity structure (Figure 4), the shortest maturities of less than 1 month were consistently the most frequently concluded transactions, but the number of daily transactions has decreased somewhat in this maturity category since 2011. In the 1-3-month maturity bucket, there was a trend-like increase since the beginning of the time series. 


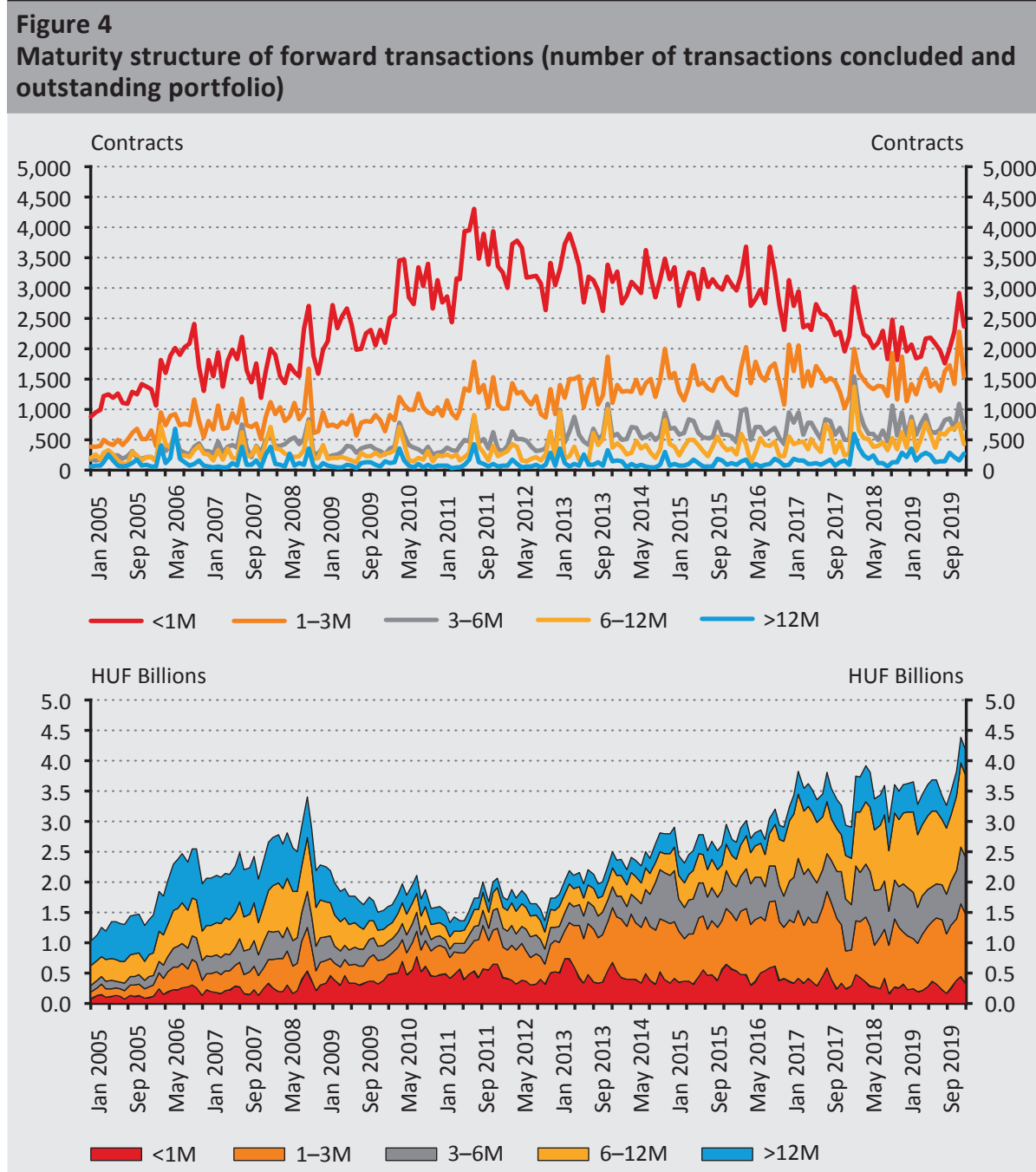

Source: Edited based on MNB (D01)

The maturity structure of outstanding transactions shows a different picture compared to transactions. Two-thirds of the outstanding portfolio has a residual maturity of over 3 months, while for transactions this ratio is only around onequarter. Shorter transactions need to be renewed more frequently by the participants, while the lower volume of forward transactions concluded for longer maturities is offset by the longer maturity of these transactions. The increase in the outstanding stock of forwards in recent years is also largely attributable to longer maturities. 


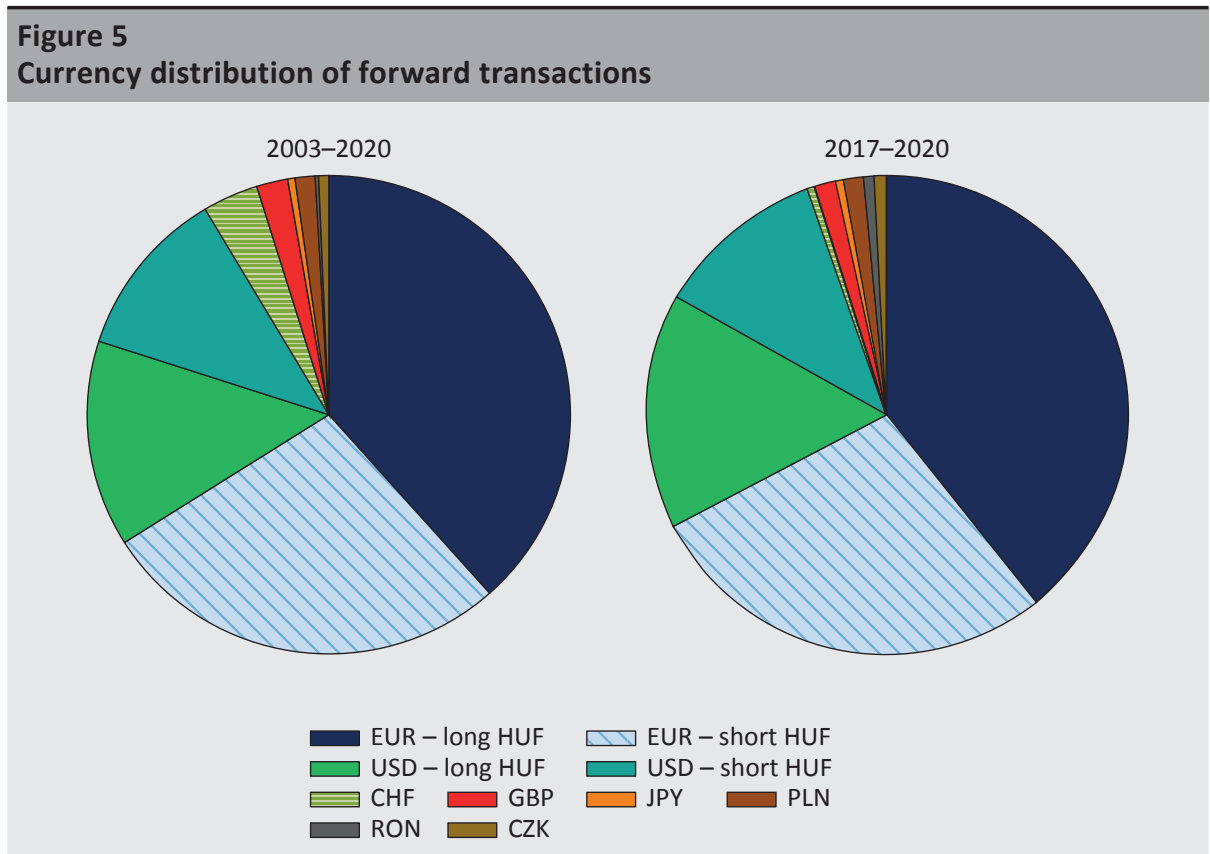

Note: In the case of EUR and USD, the FX ratio is further broken down into short and long HUF transactions (from the point of view of the banks' counterparties: in the case of short HUF transactions the counterparty buys HUF in a forward transaction from the domestic bank).

Source: Based on MNB data

Regarding the currency breakdown, it seems that there have not been any significant changes in recent years. Shorter forward transactions vis-à-vis the euro continue to dominate, but almost two-thirds of Hungarian transactions concluded were shortmaturity EURHUF forwards (Figure 5), representing a higher level than shown by the BIS data.

\section{Participants in the Hungarian FX forward market}

In the monthly M05 report, domestic banks report their outstanding derivatives market portfolios broken down by sector. ${ }^{3}$ Based on these, banks' customer base in the FX forward market mainly consisted of domestic clients, and the share of foreigners was low (Figure 6).

Domestic financial sector participants accounted for one-half of the portfolio. Within this category, mutual funds were particularly important, whereas transactions of insurance companies, pension funds, other financial corporations and other credit institutions represented a smaller proportion. Another nearly 40 per cent of the

${ }^{3}$ From the daily, transaction-level D01 report we can uniquely identify most of the bank counterparties in the financial sector, but (non-financial) corporate and retail customers can only be traced in the report in an aggregate manner. 
forward stocks outstanding was made up of non-financial corporations. There are no unique identifiers available for individual firms within this group; thus, we only know based on bank interviews that it is primarily non-financial firms engaged in international trade, and in particular exporters which typically use the FX forward market. Transactions with retail and municipal customers account for a smaller share of the portfolio. Interestingly, foreign players are barely present in the domestic segment of the market. The reason for this is that among non-residents, those who deal in the FX market with domestic banks (global banks, parent banks) usually generate (synthetic) forward positions through a combination of FX swaps and spot transactions (Páles et al. 2010; Csávás - Szabó 2010 explains in detail the feature and use of FX swaps).

\section{Figure 6 \\ Structure of the Hungarian FX forward market}

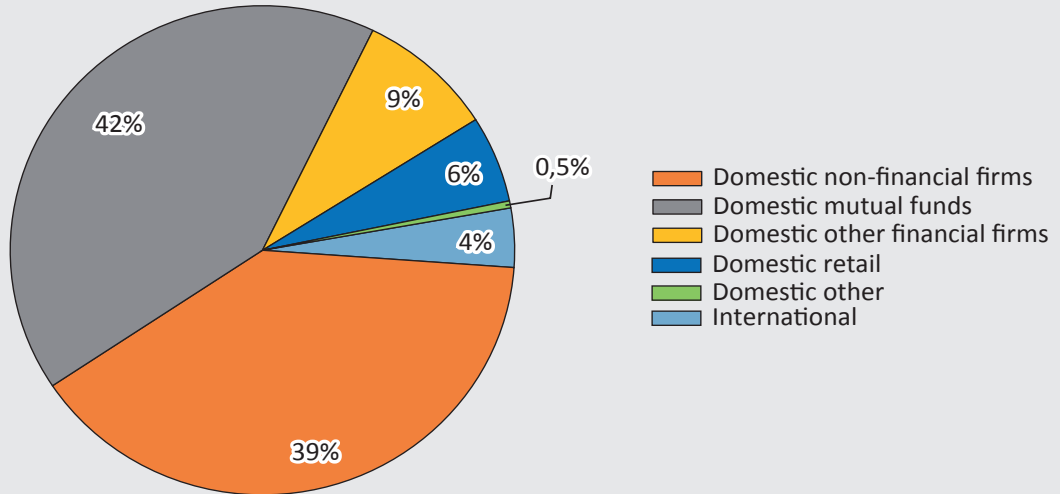

Note: Customer base of Hungarian data reporting banks on the FX forward market (March 2020). Source: MNB (M05 report)

In conclusion, the domestic forward market entails three main groups of participants: domestic mutual funds, internationally trading non-financial companies and intermediary domestic credit institutions. This structure was characteristic of the market between 2017 and 2020 with the exact shares of these sectors only slightly changing.

This section presents the FX forward market activities of these three participants.

\subsection{Data reporting banks}

Domestic banks participate as intermediaries in the FX forward market as well as in other segments of the FX market. On the one hand, FX forward positions can be produced as a combination of an FX swap and a spot transaction, and thus mispricing compared to this represents an arbitrage opportunity. On the other hand, due to macroprudential regulations, ${ }^{4}$ banks do not hold significant open FX positions

\footnotetext{
${ }^{4}$ The foreign exchange funding adequacy ratio (FFAR) requires holding sufficient amount of stable foreign currency funding in proportion to foreign currency assets. The foreign exchange balance ratio (FXBR) puts a ceiling on the degree of currency mismatch between assets and liabilities relative to the total balance sheet.
} 
(the total open FX positions relative to the total balance sheet is around half a per cent); thus, they find counterparties to close positions opening due to demand in FX forwards of non-financial corporates and mutual funds in the other two FX market segments (and vice versa: the forward market is also used for offsetting transactions concluded on the other two markets).

To take an example, exporter demand for forint buying in the forward market (long HUF forward) opens the bank's FX position in the direction of increasing its net FX assets, which the bank can cover (other than selling a short HUF forward) by spot selling of foreign currency obtained from the FX swap market (Figure 7). In this case, on the forward leg $\left(T_{1}\right)$ of the FX swap, the bank has to repay foreign currency, for which it can use the foreign currency it obtains from the forward transaction. Any changes in the exchange rate move the value of the forward transaction and the FX swap's forward leg by the same extent with opposite signs.

\section{Figure 7 \\ Flow of FX liquidity in the case of export revenue hedged with forward transaction and hedged bank FX position}

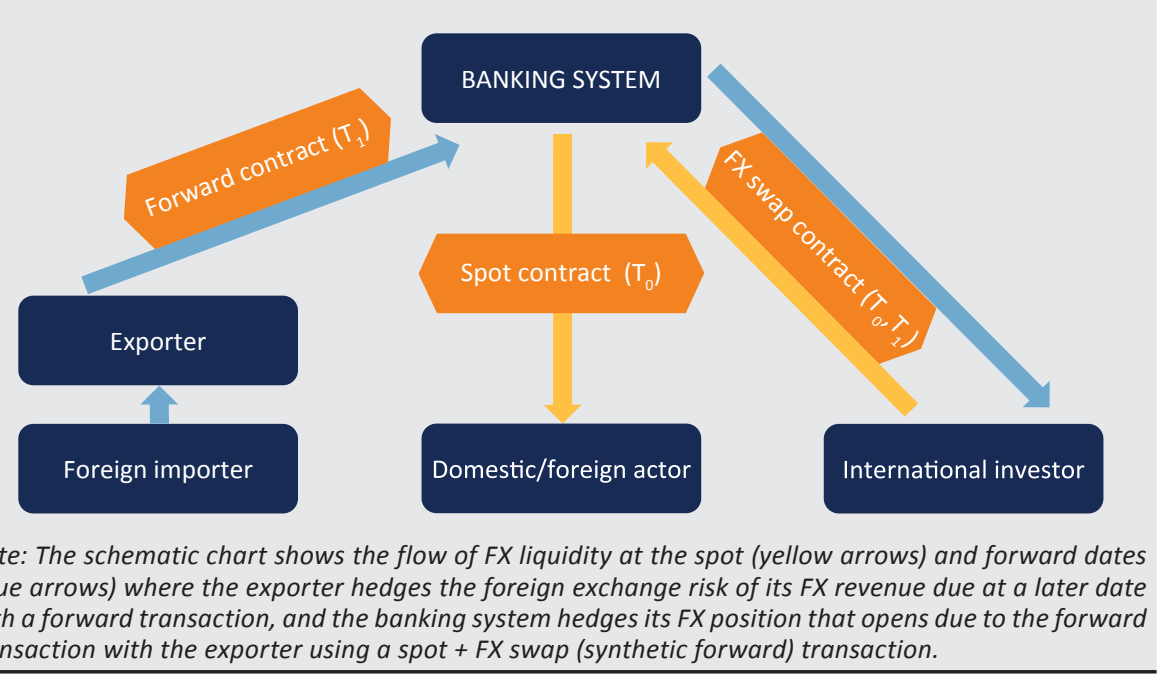

\subsubsection{Sectoral portfolios in relation to the forint}

Both major client groups of domestic commercial banks, i.e. domestic non-financial corporations and domestic mutual funds, typically maintained a net long HUF position, and thus their stock of long HUF forwards (HUF buying and FX selling in the forward market) exceeded their stock of short HUF forwards. Therefore, the Hungarian banking system took on a net short HUF position in the forward market, but closed this FX position vis-à-vis the foreign sector in the spot market. 
The gross short HUF and long HUF stocks of domestic financial and non-financial corporations showed similar dynamics. On the long HUF side, we saw a significant increase in stocks in the spring of 2017, in April 2018, in the second and third quarters of 2019, and in the first two months of this year. These waves of increases, although with different amplitudes, were present in both sectors. These periods coincided with periods of forint depreciation and resulted in increases in not only the gross but also the net long HUF forward positions (Figure 8).

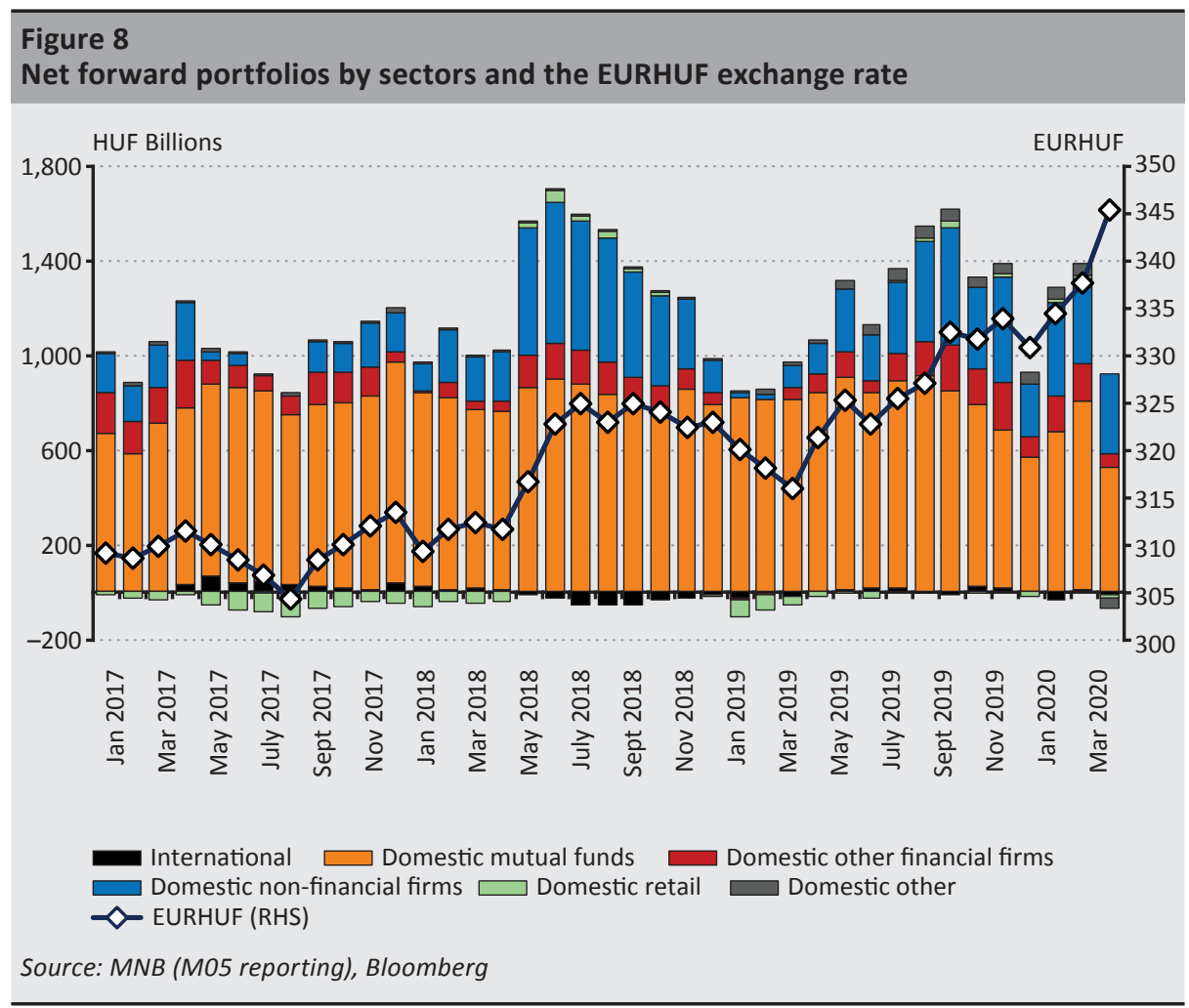

There were a few temporary increases in short HUF stocks in mid-2017 and at the very end of 2018, and at the end of 2019 (mostly in parallel with the increase in the long HUF stock).

\subsubsection{Management of counterparty risk: margin accounts and margin calls}

As mentioned, domestic banks hold low open net FX market position, but still face significant counterparty risk through their outstanding gross short and long contracts. At the time of initiation, the value of a forward contract is approximately zero as it is priced to the prevailing exchange rate and interest rates. However, 
subsequent changes in the exchange rate changes during the life of the contract change the market value of the forward, to the same extent, but in opposite directions for the short and long position holders. Finally, at the maturity of the transaction, the counterparty with the negative position transfers the loss to the profit-making counterparty. This transfer at maturity represents counterparty risk due to the default risk of the loss-making party.

There are several established practices for managing counterparty risk. Commercial banks mark to market the value of forward transactions with financial and retail clients on a daily basis and the bank requests liquid collateral to cover any losses on these positions. If the bank does not receive the collateral, it closes the position with a reverse transaction.

Most of the banks surveyed choose a different procedure for non-financial corporates. In this case, the banks' risk management divisions assess the profile of firms in advance and set limits for forward transactions in a framework agreement. These framework agreements allow taking positions in a direction that is in line with the natural hedge of the firm (for exporters, long HUF position, for importers short HUF position) and is typically somewhat lower than (annual) sales revenues. Such frameworks keep counterparty risk low. For example, if the forint weakens, and this makes long HUF positions loss-making, the HUF value of FX revenues from export sales also increase in parallel for exporters. Thus, it is realistic to assume that the loss from a forward transaction can ultimately be offset by the firm. Therefore, margin calls and the practice of automatically closing out transactions are also rare.

\subsubsection{Market concentration}

15-25 financial institutions have participated in the Hungarian forward market in the last 10 years, and $8-10$ of these banks can be considered more active. Over the years, the number of participating banks decreased, but this was a result of smaller players exiting the market, and accordingly indicators of market concentration did not change much.

The Herfindahl-Hirschmann Index, which sums the squares of market share (and multiplies by 10,000), fluctuated between 1,000 and 1,500 for most of the period, suggesting a low to medium concentration. The market share of the three largest players ranged from 50 to 60 per cent.

\subsection{Non-financial firms active in international trade}

According to the unanimous responses of the banks contacted, in the non-financial corporate sector, companies active in international trade play a key role in the FX forward market. Within this sector, exporters were more dominant, although the relative role of importers has increased in a trend-like manner over the past 
decade. Despite the trend, exporters still represent a greater weight in the market, which was reflected in the consistently positive (long HUF) net forward stock of the domestic corporate sector.

There are several factors behind the larger, but relatively declining, role of exporters. In addition to hedging their natural FX exposure, both speculation on forint strengthening following periods of weakening and carry trade considerations played a role in exporters' forward position taking. Based on several bank interviews, in recent years corporate perception of these factors changed noticeably.

\subsubsection{Forward positions as natural hedges}

The literature deals in detail with hedging the natural FX position arising from international trade. Exporters receive their revenues in the future and typically at a price fixed in foreign currency, so until the revenue is realised, the change in the exchange rate poses a risk to the balance sheet: HUF strengthening reduces the sales revenue measured in forints. This risk can be mitigated by a transaction with a long HUF forward contract (forint buying and foreign currency selling in the forward market), since HUF strengthening would make a profit on this forward position offsetting the loss in the export revenue. The foreign currency borrowing has a similar effect: HUF strengthening decreases the forint value of FX liabilities (or, in a flow approach, the forint value of interest paid on FX liabilities), which results in a profit.

Similarly, in the case of importers, the exchange rate risk of future FX expenditures can be mitigated by a forward short HUF transaction (forward forint sale, foreign currency purchase) or by including FX assets in the balance sheet. As the Hungarian international trade balance has typically been in surplus over the past decade, but net exports have declined since 2016 , this, by itself, explains the net long HUF but relatively declining hedging in the forward market.

An (admittedly imperfect) indication of the extent of hedging the FX exposure due to exports and imports of the corporate sector is the ratio of on-balance-sheet FX assets, FX liabilities and FX derivatives to international trade volumes (Figure 9). ${ }^{5}$

\footnotetext{
${ }^{5}$ In a stock-based approach, hedging could theoretically be assessed by comparing on the one hand the value of assets (inventories) held on the balance sheet intended for export / import, but which are subject to be revalued due to exchange rate fluctuations, to the value of on-balance and off-balance-sheet financial items. A first problem is that we only have data at the sectoral and not at the individual firm level, and exports and imports of the same firm already constitute a natural hedge against exchange rate risk (this in itself reduces the needed hedge by financial instruments). On the other hand, instead of the revalued stock, we can observe the export / import turnover. Although the two are related, their volume can vary significantly depending on how many months the products stay in the balance sheet. In the literature, Borio et al. (2017) also use metrics similar to what we use.
} 
The volume of FX forwards fluctuated between 2 and 7 per cent of (12-month) exports and imports of goods, and after the crisis of 2008-2009, the forward stock of the non-financial corporate sector decreased significantly compared to the total volume of international trade. Interestingly, this was (at least between 2009 and 2012) accompanied by a relative increase in on-balance-sheet FX assets and liabilities.

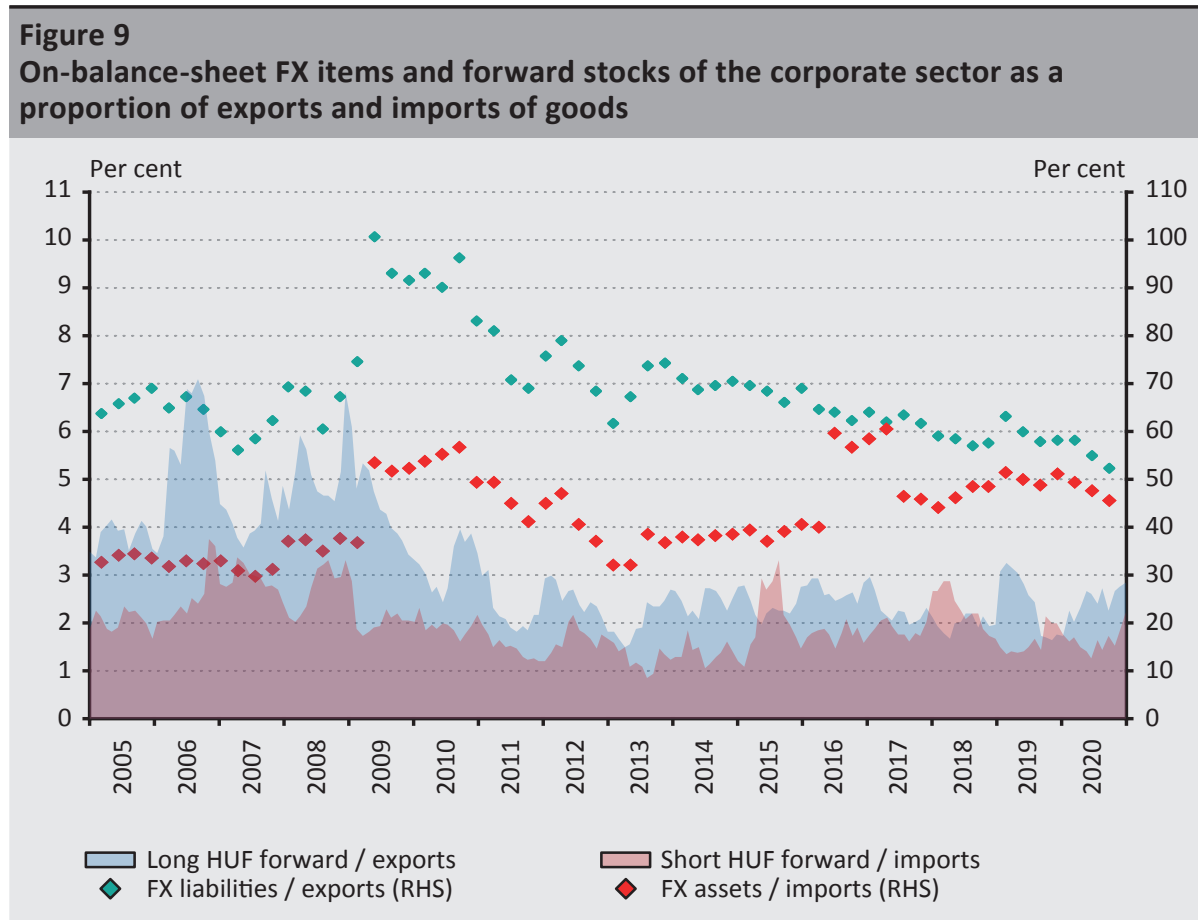

Note: Non-financial corporate sector FX-denominated on-balance-sheet financial assets and liabilities, stocks of forwards recorded in D01 as resident counterparty each compared to the volume of exports and imports of goods in the last 12 months.

Source: MNB (D01 reporting, Balance of Payments Statistics)

The FX liabilities of the non-financial corporate sector (FX loans, issued securities, other FX liabilities) exceed their FX assets (mainly FX deposits, securities), which is - on the whole - consistent with the "natural hedging" of the net exporter position. On a gross basis, on-balance-sheet financial FX assets and FX liabilities significantly exceed the stock of forward derivatives, and thus a significant part of the FX exposure may be covered by on-balance-sheet items. On-balancesheet items as well as FX forwards were higher as a proportion of exports than imports. 


\subsubsection{Speculative and carry trade content of forward positions}

In addition to hedging their natural FX positions, it is also easy to identify a speculative motive for forward trading (betting on EURHUF mean reversion) by exporters as already described by Csávás et al. (2006). In periods of forint depreciation, exporters (with the exception of the spring of 2020) generally increased their long HUF positions (Figure 8), because during these periods expectations of forint appreciation become stronger. Therefore, exporters hedged a larger share of their expected revenues in these periods. ${ }^{6}$ If exporters did not have mean reverting exchange rate expectations, this pattern would not be observed. On the other hand, several of our bank respondents mentioned the gradual weakening forint exchange rate in recent years as a factor that reduced the interest of exporters in the forward market, because due to this, in the event of further depreciation exporters were less likely to expect the forint to strengthen again. On the other hand, the weakening of the forint, if it affected expectations, could also have strengthened the short HUF position taking by importers.

Finally, the forward rate is typically higher than the spot rate due to the interest rate differential between the forint and the euro (or the dollar). This is justified by the covered interest rate parity. ${ }^{7}$ But as forint money market rates have gradually declined over the past decade, much of this differential has melted away relative to euro and dollar money market rates. As a result, while in the past the forward exchange rate was significantly higher than the spot exchange rate, and thus, exporters received a larger HUF amount for their currency in the forward market than in the spot market, due to the smaller interest rate differential this attractiveness has decreased significantly in recent years. ${ }^{8}$ Falling forint interest rates also significantly reduced the carry trade-type motivation of long HUF forward exposures based on the interest rate differential. In part, this may also contribute to the difference between older (Bodnár 2006, 2009) and newer (Harasztosi - Kátay 2020) literature results related to the importance of the interest rate differential.

\footnotetext{
${ }^{6}$ Our banking interviews also confirm the transactions of exporters motivated by their expectations of exchange rate mean reversion. As a rule of thumb, according to one of the banks, firms active in the forward market hedge between one-third and two-thirds of their export revenues with forward transactions. The ratio typically reaches its upper limit when the exchange rate depreciates. Corporates, however, do not usually fully hedge exports partly because of prudential reasons (they do not risk over-hedging), and in many cases because the bank limits on forward positions are set below that level. Also, the transaction costs of forwards also favours under-hedging.

${ }^{7}$ If the forward exchange rate was not higher by the interest rate differential than the spot rate, an arbitragefree profit could be made by holding the higher interest currency funded by the low interest currency and the FX risk hedged by a forward.

${ }^{8}$ Based on the theory of uncovered interest parity, a higher interest rate differential carries a higher risk of exchange rate depreciation. However, the empirical validity of UIP is controversial and this constitutes one of the great puzzles of finance, the forward premium puzzle (Fama 1984). This puzzle motivates the (FX) carry trade strategy, which constitutes investing in high-interest currency assets financed by low-interest currency funds.
} 


\subsection{Mutual funds}

Based on our bank interviews, the primary motivation of mutual funds to participate in the FX forward market is to partially hedge the currency risk of their portfolio. Partial hedging is in line with international experience. Based on the references reviewed by Melvin - Prins (2015), investors in the financial sector with an international equity portfolio hedge half of the exchange rate risk of their portfolios, and in some cases an even larger share. According to Borio et al. (2017), the observed hedge ratio was 20-60 per cent for international equity investors and 50-100 per cent for international bond portfolios.

Partial hedging of the exchange rate risk of balance sheet items (as opposed to full hedging) does not necessarily denote speculation, as it can also result from purely risk management purposes. The correlation between exchange rate risk and other risks (e.g. interest rate risk) may yield a lower optimal hedge of the exchange rate exposure. The correlation between yields and exchange rates may also cause existing interest rate derivatives to already partially hedge the FX exposure (Mun 2016). In addition, higher exchange rate exposure may have diversification benefits in international equity investments (Massa et al. 2016). Au - Somefun (2018) furthermore points out that due to the correlation between stock prices and FX rates, international equity investments not hedged against FX rates (based on the MSCI World Index) had lower volatility than the hedged index between 2008 and 2015. At the same time, the net forward stocks of mutual funds typically increased during periods of forint depreciation, which suggests similar speculation-motivated trading (betting on exchange rate mean reversion) as in the case of non-financial corporates.

Hungarian mutual funds mostly finance their assets by HUF-denominated mutual fund shares, against which funds with international investment portfolios hold FX assets. The weight of FX assets (equities, FX bonds and deposits, and other mutual fund shares) is significant in mutual funds' investment portfolios. The weight of FX liabilities is typically smaller in the balance sheets, and thus funds are characterised by a positive net FX position (Figure 10). The distribution of mutual funds in this respect is characterised by a $50-40-10$ per cent proportion of positive - neutral negative FX positions.

The positive net FX exposure justifies a long HUF forward stock (for funds that want to hedge at least part of this exposure), and indeed mutual funds (similarly to nonfinancial firms) hold a significant long HUF forward portfolio at the sector level. 


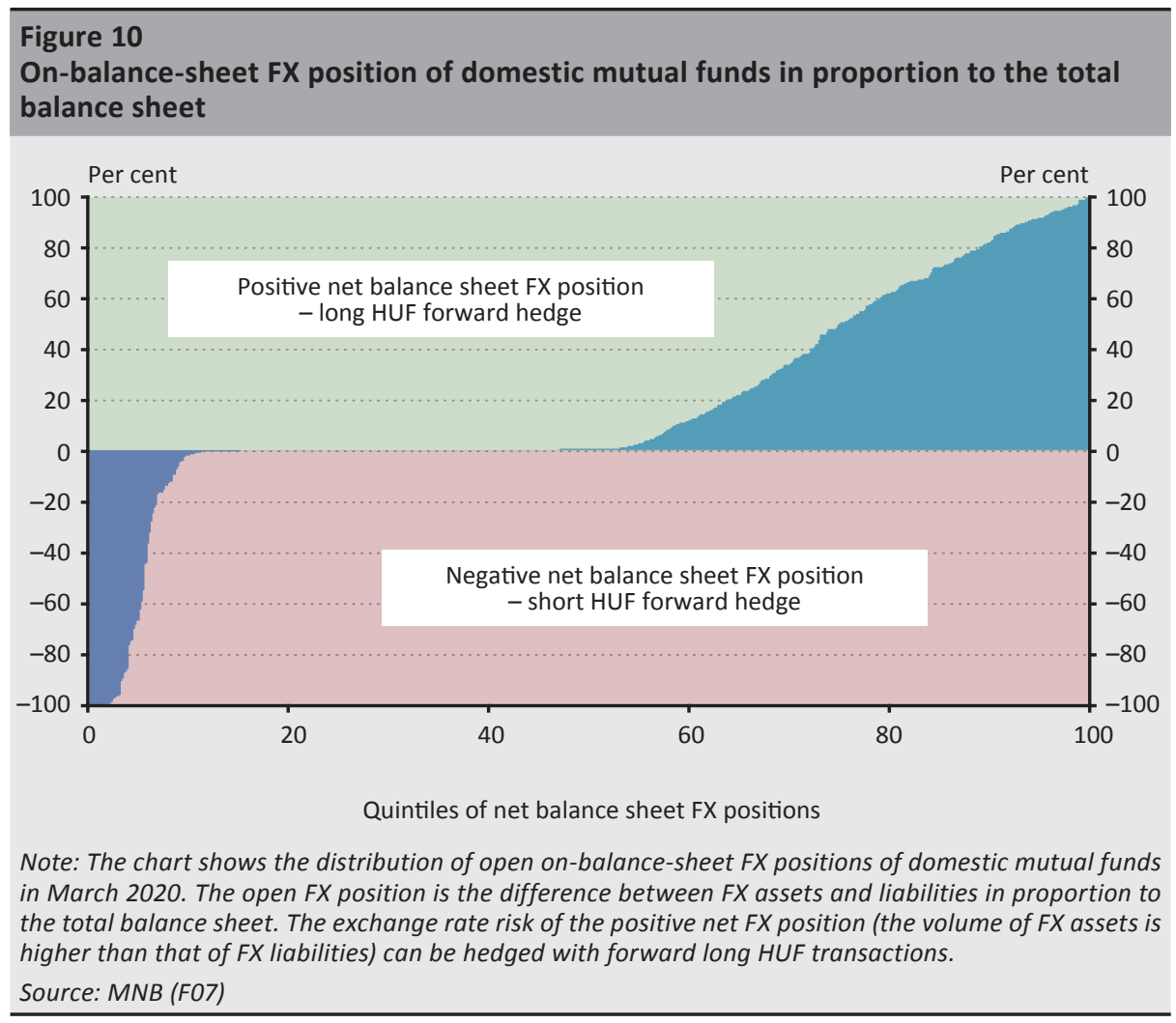

Mutual funds are also active on the short HUF side, but to a much lesser extent. This may be justified by funds investing in the domestic securities or real estate market funded by FX liabilities. About one-fifth of the stock of mutual fund shares issued by domestic mutual funds is denominated in foreign currency, mostly in euros. Some of these funds finance HUF assets - and thus the FX liabilities of approximately onetenth of all mutual funds exceed their stock of FX assets. Due to their negative net on-balance-sheet FX position, these mutual funds appear on the forward market as forint sellers, provided that they want to hedge at least part of the exchange rate exposure due to HUF assets and FX liabilities.

At the sector level, the positive on-balance-sheet open FX position of mutual funds accounts for about 26 per cent of the total balance sheet, however, depending on the investment strategy, there are significant differences between fund types (Figure 11). Equity funds and international (mainly equity, derivative, guaranteed and mixed) funds have the largest on-balance-sheet FX positions. These types of funds have significant stocks of foreign assets. In addition, the on-balance-sheet FX exposure of real estate funds is significant: their FX assets account for twice their FX liabilities. The relatively significant net on-balance-sheet FX position of real estate 
funds is justified on the one hand by the fact that in the domestic office market and in the case of commercial real estate settlement in euros ${ }^{9}$ is general (the main income sources, rents are typically calculated in euros). In addition, investment in foreign assets - either directly or indirectly in collective real estate investment securities or non-real estate financial assets - may also take place, due to the geographic diversification of real estate funds' asset portfolios. Other (derivative, mixed, venture capital) domestic funds and money market funds have the lowest FX exposure: the portfolio of these mutual funds has a lower weight of foreign investments and the FX composition of financing is in line with the composition of their assets.

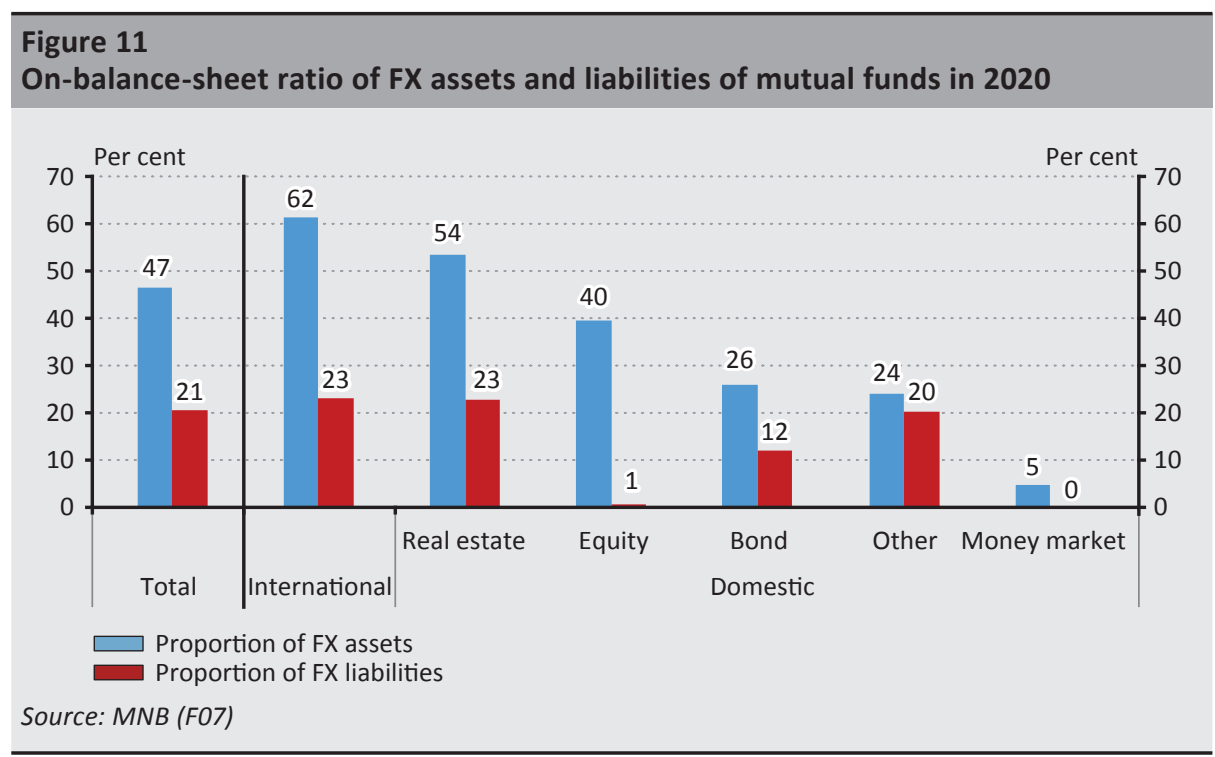

The FX exposure of mutual funds has increased in total by almost HUF 1,800 billion since 2009, which is mainly attributable to international funds and real estate funds, and to a lesser extent to domestic bond funds (Figure 12). However, the open positions of mutual funds as a proportion of the total balance sheet has changed less over the years, ranging from 20 to 30 per cent, i.e. the increase in the nominal amount of FX exposure has been roughly proportional to the expansion of mutual fund balance sheets.

First, in line with the favourable post-crisis capital market developments, mutual fund shares increased in increasingly popular international funds, and then in real estate funds in parallel with the expansion of the domestic real estate market

\footnotetext{
${ }^{9}$ For more details on the domestic commercial real estate market, see the Commercial Real Estate Market Report (MNB 2020).
} 
from the second half of 2010s. At the same time, money market funds - that could provide lower yields in the low-yield environment - and from 2017 onwards bond funds lost market share. Owing to these developments, an increase in the market weight of fund types with higher FX exposures led to an increase in the net FX position of the entire mutual fund sector. There is a perceivable correlation of the open position as a proportion of the total balance sheet and the net FX position of international funds.

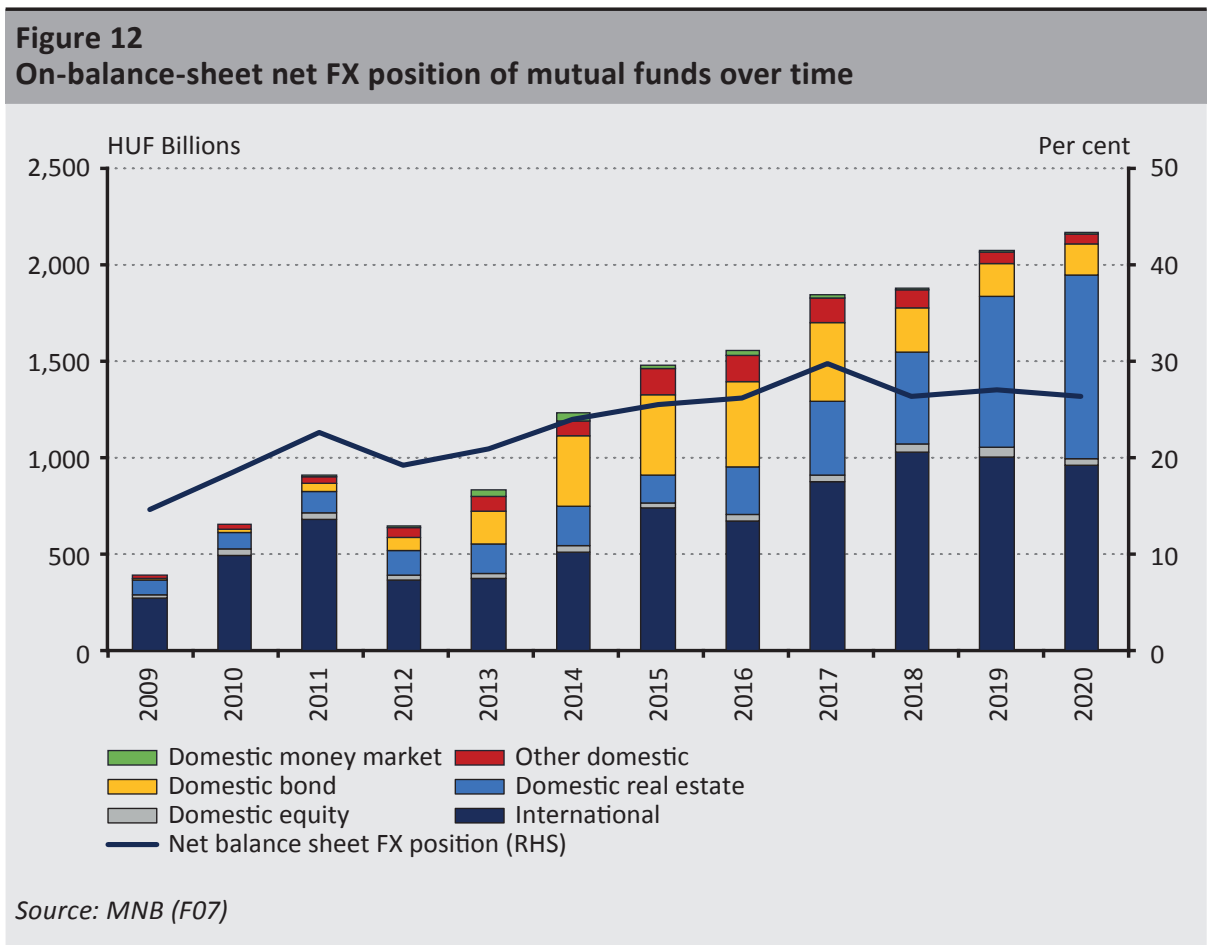

Based on D01 data, the total gross forward stock and net long HUF positions of mutual funds have risen in a trend-like manner over the last decade consistently with the balance sheet and total net FX position of mutual funds, ${ }^{10}$ although since 2017 - based on M05 data - the net long HUF position has decreased. The M05

\footnotetext{
${ }^{10}$ Based on the D01 data, there is no direct observation, but only an estimate regarding the forward stock of mutual funds. When explaining the sources of data, we mentioned that based on the M05 report available since 2017, we see the monthly development of forward stocks by sector, and thus for mutual funds as well. In the D01 report, which has been available for a longer time, for many transactions, banks also indicate the unique identifiers of the counterparties, from which the stocks could be aggregated into mutual fund subtypes. However, based on the consistency analysis of D01-M05 between 2017 and 2020, this counterparty identification is not complete: some banks report transactions with funds in the anonymous category, which is why D01-based aggregation accounts for about half of the M05-based stock for mutual fund forwards. We have two types of estimates: (1) an estimate for the forwards that these banks could have traded with mutual funds based on M05 data for 2017-2020, and (2) the exclusion of these banks from the sample. Both estimates support a trend-like increase.
} 
data set shows that in 2017 about half of the open on-balance-sheet FX position of mutual funds was hedged by FX forwards (Figure 13). Hedging decreased from this level to the 25-30 per cent range in recent years, and mutual funds thus assumed a larger share of FX risk.

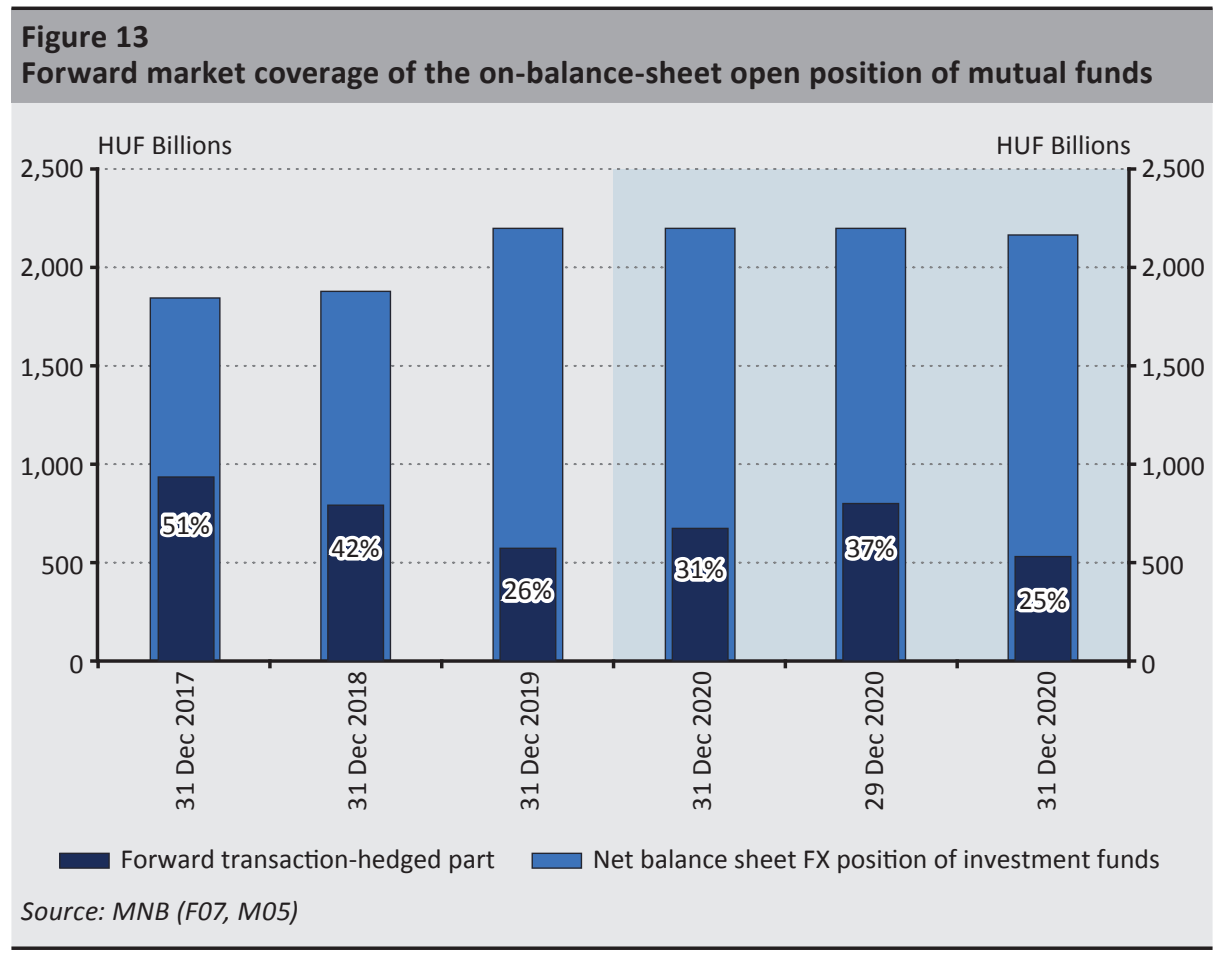

The declining net forward stock during this period is therefore not consistent with the increasing aggregate FX exposure, which would have called for an increase in the stock from a risk management perspective. Taking on a larger exchange rate position may have been a result of the relative decline in HUF interest rates, for example, in relation to rising USD yields, which constituted an increase in the cost of carry of long HUF forward transactions. It is conceivable that in the maturing business cycle, funds increasingly expected depreciation of emerging currencies and thus the forint as well. Additionally, a stronger negative correlation between the exchange rate and international equities in the face of rising market tensions could also have supported lower FX risk hedging. 


\section{Exchange rate sensitivity of FX forwards}

In this section, we provide estimates of the time-varying exchange rate sensitivity of FX forwards.

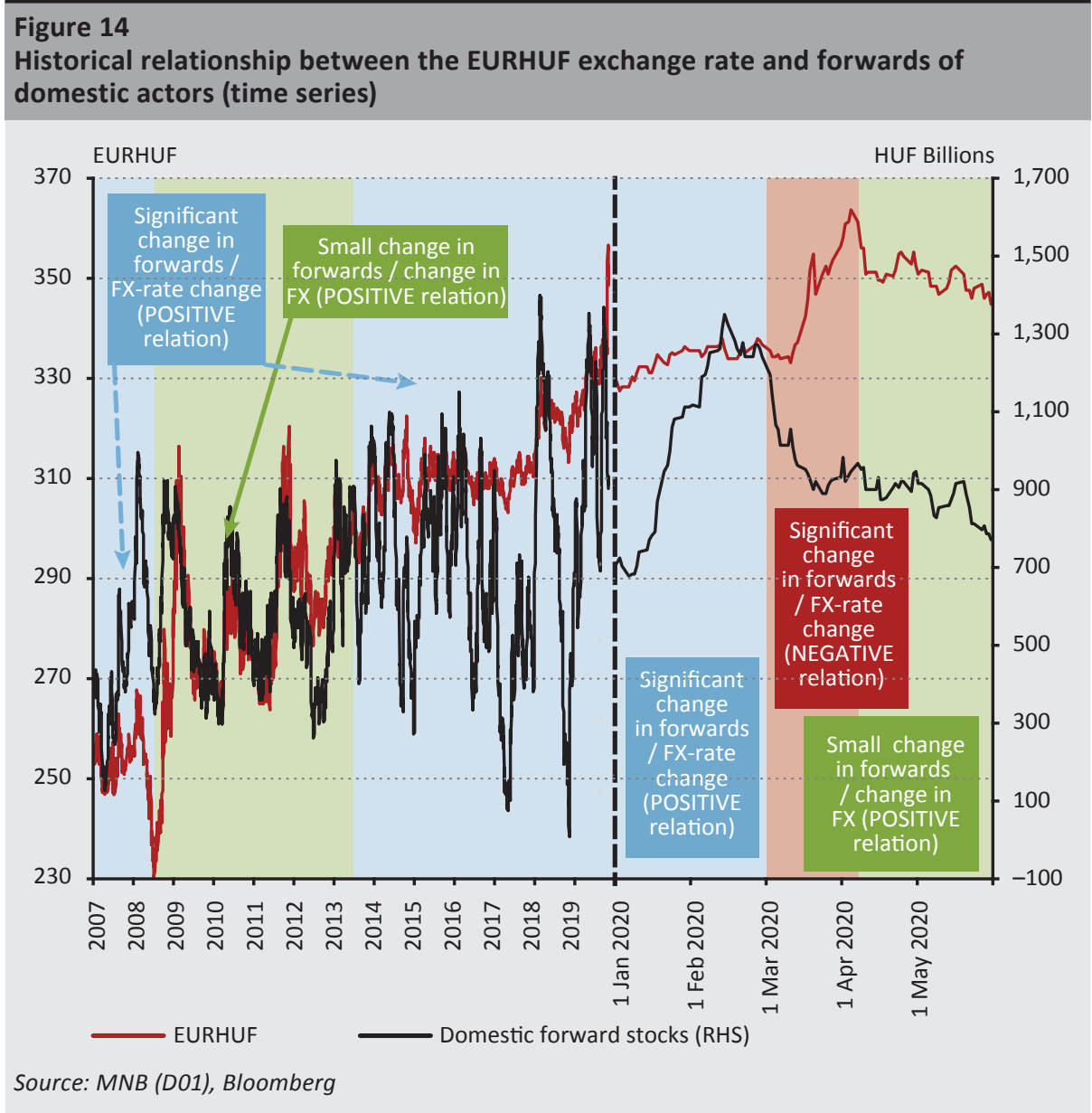

Our bank interviews, the existing literature (Csávás et al. 2006) and MNB data all suggest that the stock of forwards of domestic bank clients responds significantly to changes in the exchange rate. When the forint weakens (EURHUF increases), residents increase their net long HUF forward position, which is consistent with expectations of forint stability, hence a speculative trading motive. If increasing 
forwards also affected the exchange rate, then this negative feedback would act to stabilise the forint.

Nonetheless, the exchange rate sensitivity of the forward stock changed noticeably from time to time, and an exceptional temporarily negative correlation was also observed in March 2020, when the EURHUF exchange rate rose and the net long HUF forward stock of residents decreased (Figure 14).

To capture the time-varying sensitivity, we estimate a time-varying parameter model between forwards and the exchange rate. In the model, the EURHUF exchange rate is assumed to be exogenous. ${ }^{11}$

The measurement equation of the model is:

$$
\Delta F W D_{t}=c_{0 t}+c_{1 t} \Delta F W D_{t-1}+\beta_{0 t} \Delta \mathrm{EURHUF}_{t}+\beta_{1 t} \Delta \mathrm{EURHUF}_{t-1}+\varepsilon_{\mathrm{t}}, \varepsilon_{t} \sim N(0, R) .
$$

where $\triangle F W D_{t}$ is the change in the logarithm of the forward stock, ${ }^{12}$ which is assumed to be determined by a factor independent of the exchange rate $\left(c_{0 t}\right)$, an autoregressive term (with parameter $c_{1 t}$ ), the effect of the logarithm of contemporaneous and lagged EURHUF exchange rate changes (with parameters $\left.\left[\beta_{0 t}, \beta_{1 t}\right]\right)$, and a normally distributed error term $\varepsilon_{\mathrm{t}}$.

Let $B_{t}$ denote the vector of latent parameters $\left[c_{0 t}, c_{1 t}, \beta_{0 t}, \beta_{1 t}\right]$ at a given time. We use a random walk assumption for the dynamics of this parameter vector:

$$
B_{t}=B_{t-1}+v_{t}, v_{t} \sim N(0, Q)
$$

with innovations $\left(v_{t}\right)$ assumed to be normally distributed with diagonal covariance $(Q)$.

The model is estimated using the EM (Expectation-Maximisation) algorithm (Dempster et al. 1977) using the D01 (daily frequency) data set between 2003 and 2020. The technical details of the estimation and the robustness test are reported in the Appendix.

${ }^{11}$ Using VAR models (not reported here), we also examined more general models that allow interactions between the exchange rate, the spot transactions of non-residents and forwards (in different sectoral breakdowns). Based on Granger-causality tests, the forward transactions (and spot transactions of non-residents with domestic banks) do not have a significant lagged effect on the exchange rate. The simultaneous (intraday) effect may still be significant, but the extent of this effect cannot be identified using our daily transaction data set. The relatively smaller domestic trading compared to the global forint market however suggests that such an impact is likely to be moderate. The more significant the reverse effect of forward stocks on the exchange rate, the more our model underestimates the sensitivity of forwards to changes in the exchange rate.

12 In the Appendix, we present robustness test estimates with versions of the model where transactions (the volume of new forward contracts) are the dependent variable instead of changes in forward stocks. Similar results are obtained with those models. 


\section{Figure 15 \\ Exchange rate sensitivity of domestic forward stocks}

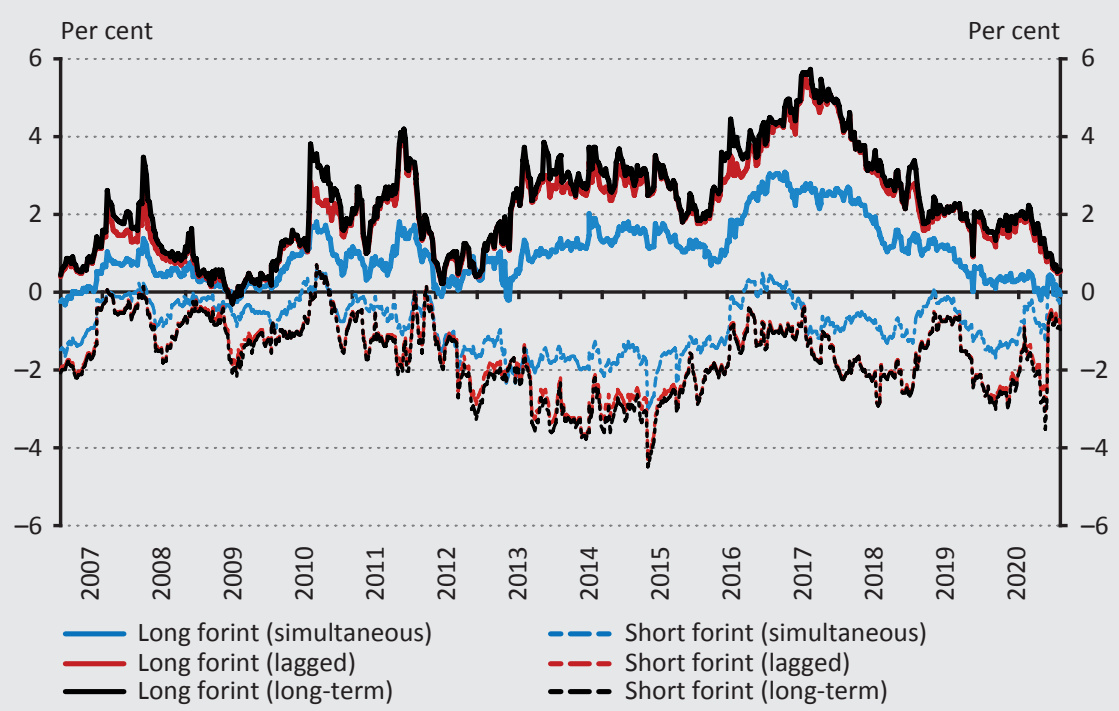

Note: Exchange rate sensitivity time series calculated on the basis of filtered model parameters (per cent change of the FX forward stock due to a 1 per cent increase in the EURHUF exchange rate - forint depreciation). Blue lines show the simultaneous effect $\left(\beta_{0}\right)$, red lines the sum of the simultaneous and lagged effects $\left(\beta_{0}+\beta_{1}\right)$, black lines the unconditional (long-term) effect $\left(\left(\beta_{0}+\beta_{1}\right) /\left(1-\left|c_{1}\right|\right)\right)$. The solid lines refer to the long HUF stocks (forward forint purchases of the bank client), the dashed lines refer to the sensitivity of the short HUF stocks (forward forint sales of bank clients).

Source: Based on MNB (D01) and Bloomberg data

Figure 15 shows the development of the exchange rate sensitivity of the domestic forward stock (simultaneous, two-period and long-term) based on the estimated (filtered) parameters. In the case of long HUF forwards, the parameters are positive, which confirms that the long HUF forward stock of domestic customers increases as the EURHUF exchange rate rises (forint weakens). By contrast, the volume of short HUF forwards increases when the forint strengthens, as evidenced by the negativity of short HUF forward parameters.

Our estimates show an important common feature of crisis periods. At the end of 2008, in 2011-2012 and this year during the coronavirus epidemic, the exchange rate sensitivity of forwards clearly decreased, meaning that in these periods much larger exchange rate movements were needed to trigger the same forward transactions than in normal periods. Although there is no systematic decrease in forward trading volumes during these periods, the contract volume linked to a unit of exchange rate movement decreases. 
Reduced exchange rate sensitivity during these periods can be interpreted in several ways. One possibility is that bank clients become more cautious (for example, due to increased volatility / expected volatility or higher liquidity requirements for potentially loss-making derivative transactions). In this case, although expectations of the mean reversion of the exchange rate persist, clients trade only on larger exchange rate movements. It is also conceivable that in periods of already high volatility and tight liquidity, bank clients - although they are willing to open speculative forward positions - do not have the capacity in terms of liquidity and capital to do so. A further interpretation is that clients' exchange rate expectations shift, or at least the customer base becomes more heterogeneous in this respect, and domestic actors become less certain about exchange rate mean reversion.

Yet another, theoretical, possibility is that the effect of domestic forwards on the exchange rate weakens during these periods. Due to the simultaneity problem of the model, if forward positions directly impact the exchange rate, this increases the estimated parameters (in absolute terms) compared to the true exchange rate effect. ${ }^{13}$ Thus, in principle, a reduced exchange rate sensitivity parameter could be a result of a reduced effect of forwards on the exchange rate. However, the low liquidity seen in the market at these times (supported by anecdotal information) does not make this explanation plausible: in illiquid markets, the same forward contract volumes are likely to have a larger, not a smaller price effect.

\footnotetext{
${ }^{13}$ For example, in the case of long HUF forward transactions, a one-unit exchange rate increase raises forwards, but forwards may act to reduce the exchange rate (strengthen the forint) compared to the original shock. Thus, we observe higher sensitivity of forwards based on observed (smaller) exchange rate changes than the true sensitivity of forwards to the (larger) original shock.
} 


\section{Figure 16 \\ Exchange rate sensitivity by sectors (Jan 2017 - May 2020 and Jan 2020 - May 2020)}
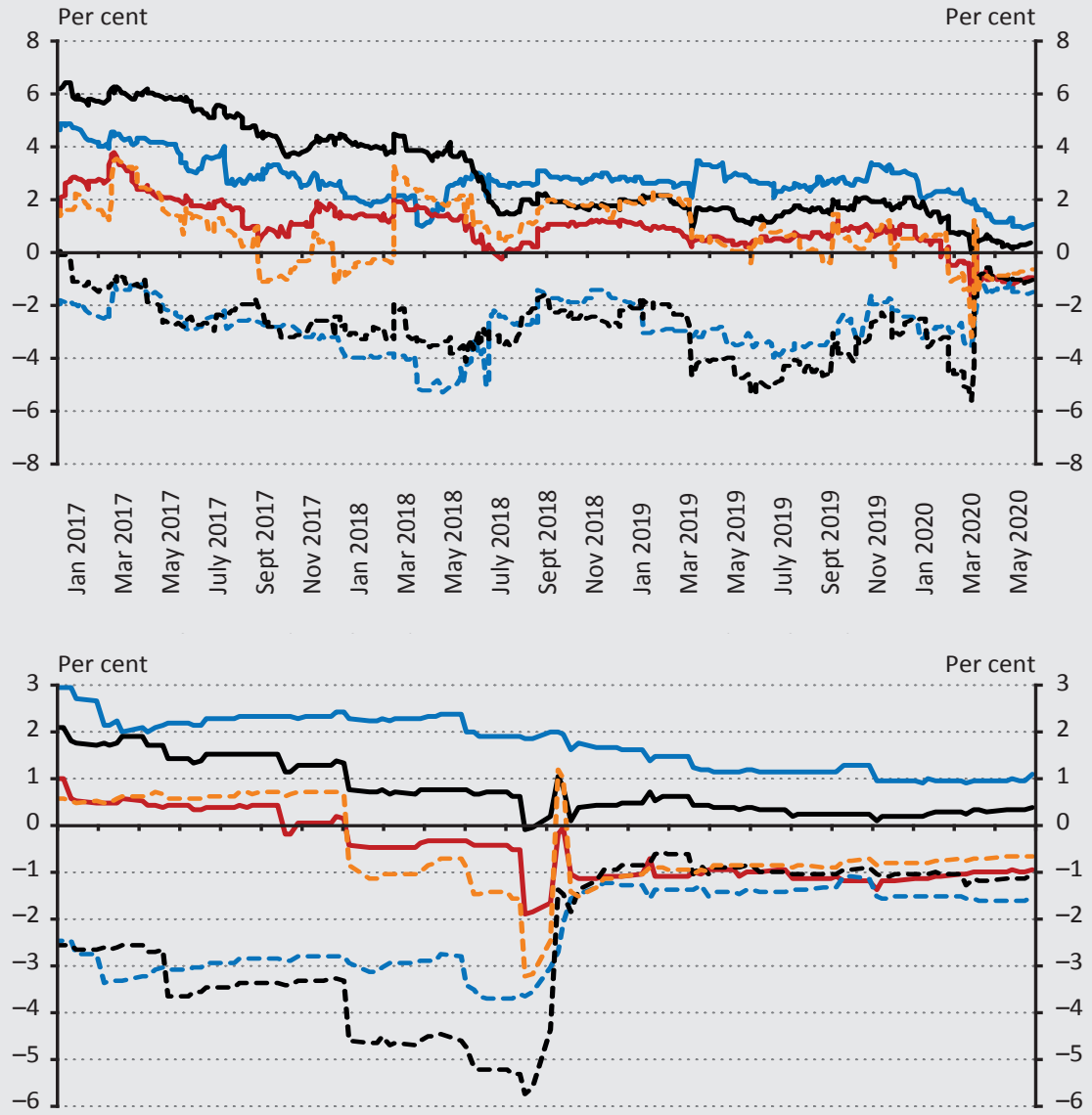

\begin{tabular}{|c|c|c|c|c|c|c|c|c|}
\hline 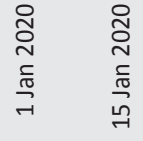 & 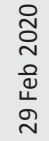 & 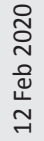 & 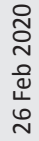 & 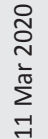 & 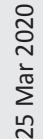 & 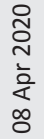 & $\begin{array}{l}\text { ㅇ. } \\
\text { } \\
\text { 产 } \\
\text { N }\end{array}$ & 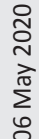 \\
\hline
\end{tabular}
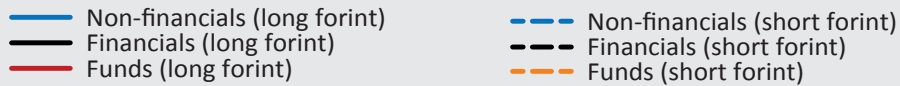

Note: Changes in the exchange rate sensitivity of forward stocks (simultaneous+lagged percentage effect on forward stocks of a 1 per cent increase in the EURHUF exchange rate - forint depreciation) according to the sectoral breakdown available from the D01 data, based on filtered model parameters. Blue lines refer to the domestic non-financial sector (corporates / retail customers), black to the domestic financial sector and red/orange to mutual funds. Solid lines depict the exchange rate sensitivity of long HUF forwards, dashed lines that of short HUF forwards. 
The D01 data provides estimates of the sectoral breakdown of forwards of bank domestic clients and we can use this to estimate exchange rate sensitivities of forward stocks for each sector (Figure 16). ${ }^{14}$ Between 2017 and 2020, long HUF forwards of both financial and non-financial clients were characterised by decreasing exchange rate sensitivity. This may be partly explained by the factors mentioned in the bank interviews, i.e. that the narrowing domestic and foreign interest rate differentials and weakening of the forint during this period moderated mean reversion speculation.

It is notable that the exchange rate sensitivity of the forward portfolio of mutual funds differs substantially from a similar indicator for the total domestic financial sector. In the case of mutual funds, the sensitivity of the long HUF forward stock to the exchange rate is much lower (although also positive), but the really remarkable difference is seen in the case of the short HUF forwards, which - in contrast to other clients - increase when the forint weakens and not when it strengthens. This suggests that speculation on stability of the forint is weaker among mutual funds than among non-financial clients (and other financial actors). At the same time, the net forward stock still correlates positively with the EURHUF exchange rate, because the volume of long HUF forwards is significantly larger than that of short HUF forwards, so a similar percentage change denotes a larger nominal increase in long HUF forwards compared to short HUF forwards.

Based on the bottom panel of the Figure 16, the exchange rate sensitivity of long HUF forwards gradually fell in 2020, whereas more substantial movements were observable for the sensitivity of the short HUF forward stock to the exchange rate. Long HUF forward exchange rate sensitivity turned negative in the case of mutual funds as early as February, while for other sectors only the positivity of the coefficient decreased. In mid-March (at the time of the forint depreciation between 13 and $18 \mathrm{March})$, the exchange rate sensitivity of short HUF forward stocks rose sharply for all domestic clients, but it only switched sign in the case of mutual funds. During this critical period, upon the increase of the EURHUF exchange rate, the short HUF forward stock held by mutual funds increased, while similar holdings of other financial and non-financial participants decreased, albeit only slightly.

\footnotetext{
${ }^{14}$ The majority of data-reporting banks report transactions with unique IDs for financial clients in the D01 report, from which we can estimate the forward stock of financial sector participants and, within that, the forward stock of mutual funds. Based on the M05 report available between 2017 and 2020, we can refine the D01 estimate (eliminate from the sample data providers for which the D01-M05 sectoral stocks differ).
} 


\section{Turbulence in the FX market in March 2020}

In March 2020, the net long HUF portfolio of the three most important domestic FX forward market clients (non-financial corporates, mutual funds and other financial corporates) declined in conjunction with a significant increase in the exchange rate, thus reversing the traditional correlation (Figure 8).

\subsection{Mutual funds were behind the decrease in the net long HUF forward position}

Mutual funds (and the entire domestic financial sector) increased their net long HUF forward exposure in January-February of this year at the time of a slight weakening of the forint. Then, in March mutual funds recorded the largest decline in net long HUF positions. The reduction of net long HUF forward exposure by other domestic financial actors (insurance companies, pension funds, other intermediaries) also contributed to the drop in total domestic net long HUF forward positions, but to a smaller extent owing to their smaller forward market share. Non-financial corporates, on the other hand, did not significantly change their net forward position.

On the financing side, the reduction of mutual funds' net long HUF position was justified by the significant withdrawal of investments from this sector as a result of the market turbulence related to COVID-19 in March. Thus, mutual funds which faced decreasing financing had to reduce investment portfolios leading to smaller open FX positions (Figure 17). International funds suffered the largest decline in shares, and within this group primarily funds with higher capital market exposure - derivative (speculative position-taking), equity and mixed (both with bond and equity exposures) mutual funds - were affected. There was no material decline in the financing of real estate funds, where the value of investments was not directly and immediately affected by the crisis, the wealth held in these mutual funds remained relatively stable. Although shares also decreased in the case of other domestic mutual fund types, this had a smaller impact on the FX forward market due to their low FX exposure. 


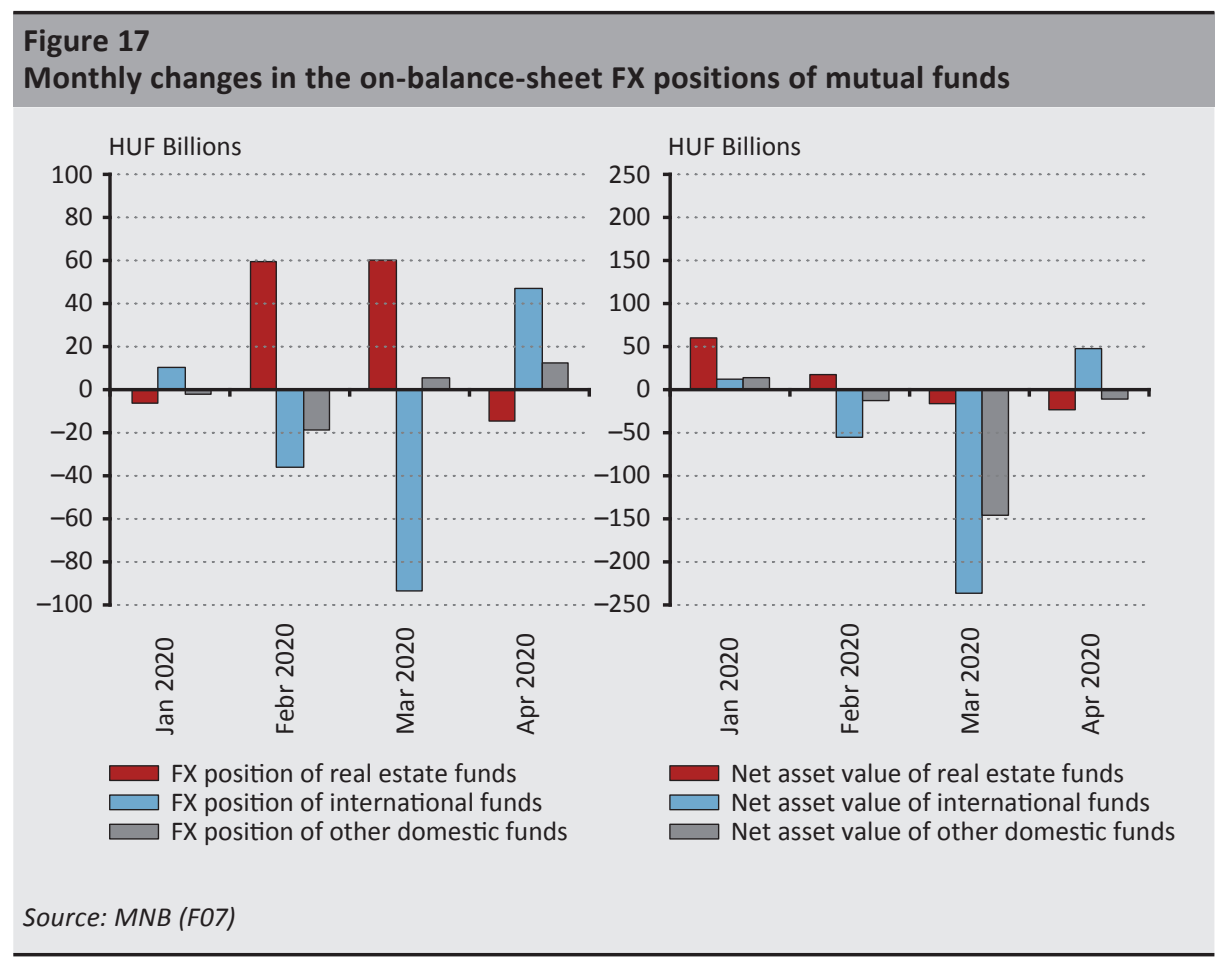

On the assets side, the exchange rate risk hedging need of mutual funds (in addition to the assets portfolio liquidated due to the aforementioned withdrawal of funds) was reduced by the fact that the market value of FX assets held on the balance sheet declined significantly, mainly due to the global drop in stock market prices. All of this primarily affected international funds (and, within this group, had a stronger influence on derivative and equity mutual funds), which typically held higher-risk assets. On the other hand, the change in the forint value of FX assets was offset by the significant depreciation of the forint against major currencies in March. This caused an increase in the forint value of FX assets (and of the smaller FX liabilities).

At the aggregate level, these two effects - the decline in international asset market values and the depreciation of the forint - broadly offset one another in terms of the forint value of mutual funds' FX asset portfolio (Figure 18). This may seem strange, given the significantly larger (around 40 per cent) decline in stock market prices compared to the weakening of the forint (below 10 per cent). This can be explained by the fact that only a part of mutual funds (e.g. equity funds, derivative funds) take higher risks, and mutual funds with significant stock market exposure also invest only a certain part of their assets in risky assets. On the other hand, most mutual funds have significant FX assets in their balance sheet. Thus, although 
the depreciation of the forint exchange rate was much smaller compared to the fall in stock prices, this latter effect may have impacted mutual funds (and their asset portfolio) more broadly than the change in the market price of risky assets.

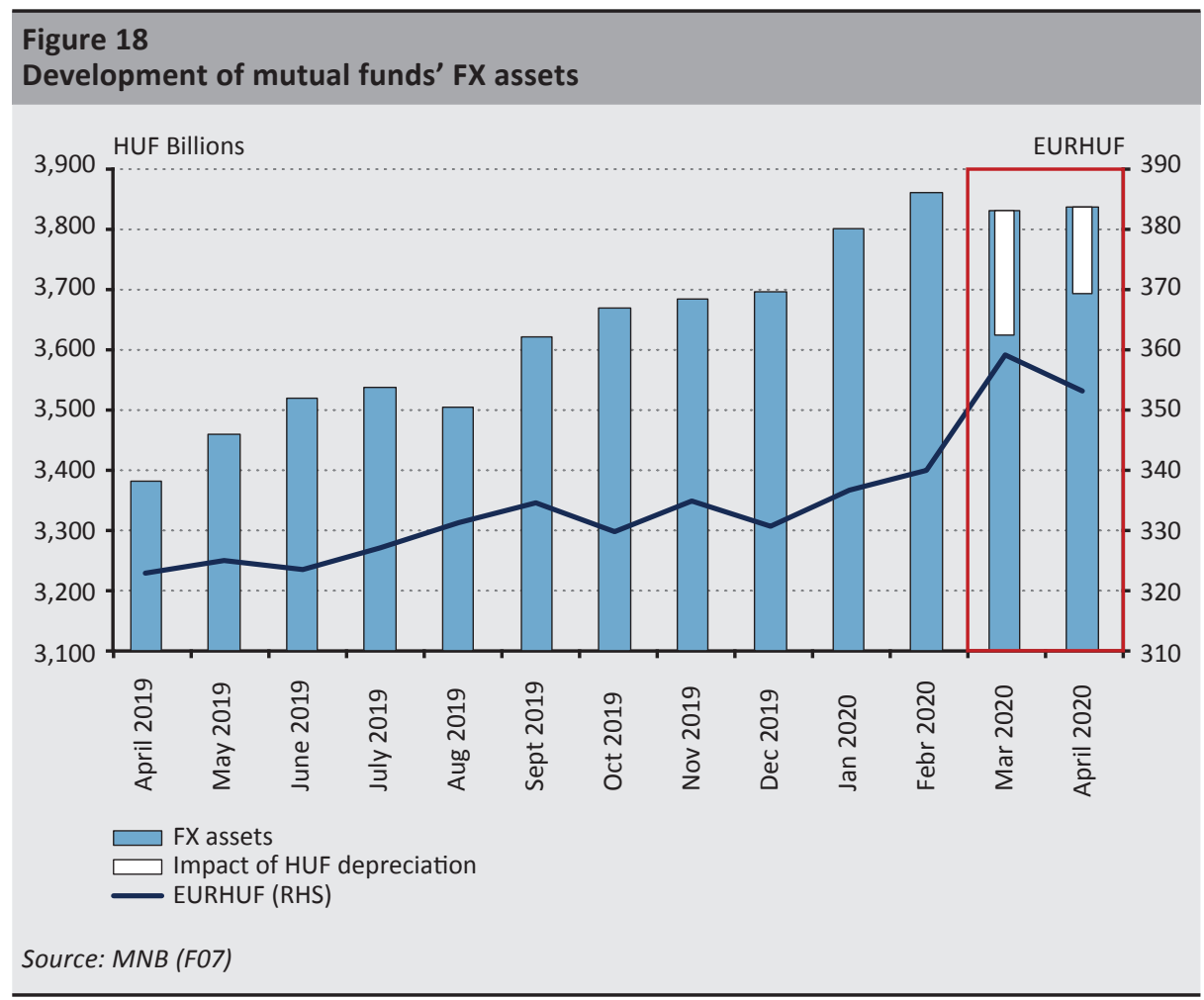

In addition, the FX forward positioning of mutual funds may also have been affected by the fact that existing stocks of long HUF forwards became loss-making due to the rise in the exchange rate. For financial actors, current European regulations require a daily marking-to-market and margining of positions and banks therefore requested additional collateral for loss-making forward contracts (margin calls). The situation was further aggravated by the increase in market volatility, which led to a narrowing of margin limits, necessitating the provision of additional collateral to roll over positions. For participants short of liquidity, margin calls also favoured the closing of forward (long HUF) positions: by closing the long positions (with new short HUF forward transactions), the resulting liquidity need could be reduced. 


\subsection{Exporters abstain from the forward market despite significant exchange rate weakening}

In the case of non-financial firms, the decline in the net forward position already started in February 2020 and was not significant in March. The small decline seems unexpected compared to the historical positive correlation with the exchange rate and the sharp increase in the EURHUF (based on which long HUF forwards would have been expected to sharply increase). Thus, exporters did not provide support for the forint exchange rate in February and March.

Anecdotal reports from banks highlighted different motivations for exporters than for mutual funds in the course of actions. One of the reasons for the smaller long HUF positions relative to the depreciation of the forint, mentioned almost by consensus, was that the participants, who wanted to hedge the exchange rate risk of their export revenues, had already entered the forward market at exchange rate levels of 330-340. Thus, in order to avoid over-hedging, they could take no more long HUF positions when the forint weakened further.

The other reasons mentioned in some bank interviews were related to the longerterm trends mentioned earlier and less to the developments in March. Such explanations attributed exporters' abstention from the forward market to the general weakening of the domestic currency in recent years and to historically lower interest rate differentials, which may have reduced traditional, speculatively motivated trading that bet on forint stability.

In principle, "stopping out" from forward transactions could also have caused the stagnation of net long HUF positions of non-financial firms, but this was also not confirmed by our bank interviews. As mentioned, for most banks, forced closings of forward positions were rare in the non-financial corporate sector and were not typical in March either.

Also, few bank respondents considered an expected decline in export revenues in the March to be a relevant factor. In this regard, the prudent under-hedging of natural exchange rate exposure was mentioned by several banks, although there were some who expected a reduction in forward exposures due to declining revenues in the coming months.

\subsection{Change in the net forward position was mainly related to the rise in the short HUF stock}

The gross long HUF forward stock stagnated after a rise in February, which thus supports the information about the absence of exporters. At the same time, it is important to emphasise that the opening of new long HUF forward positions still continued, but only to the extent to offset maturing (previously high) long HUF forwards. 


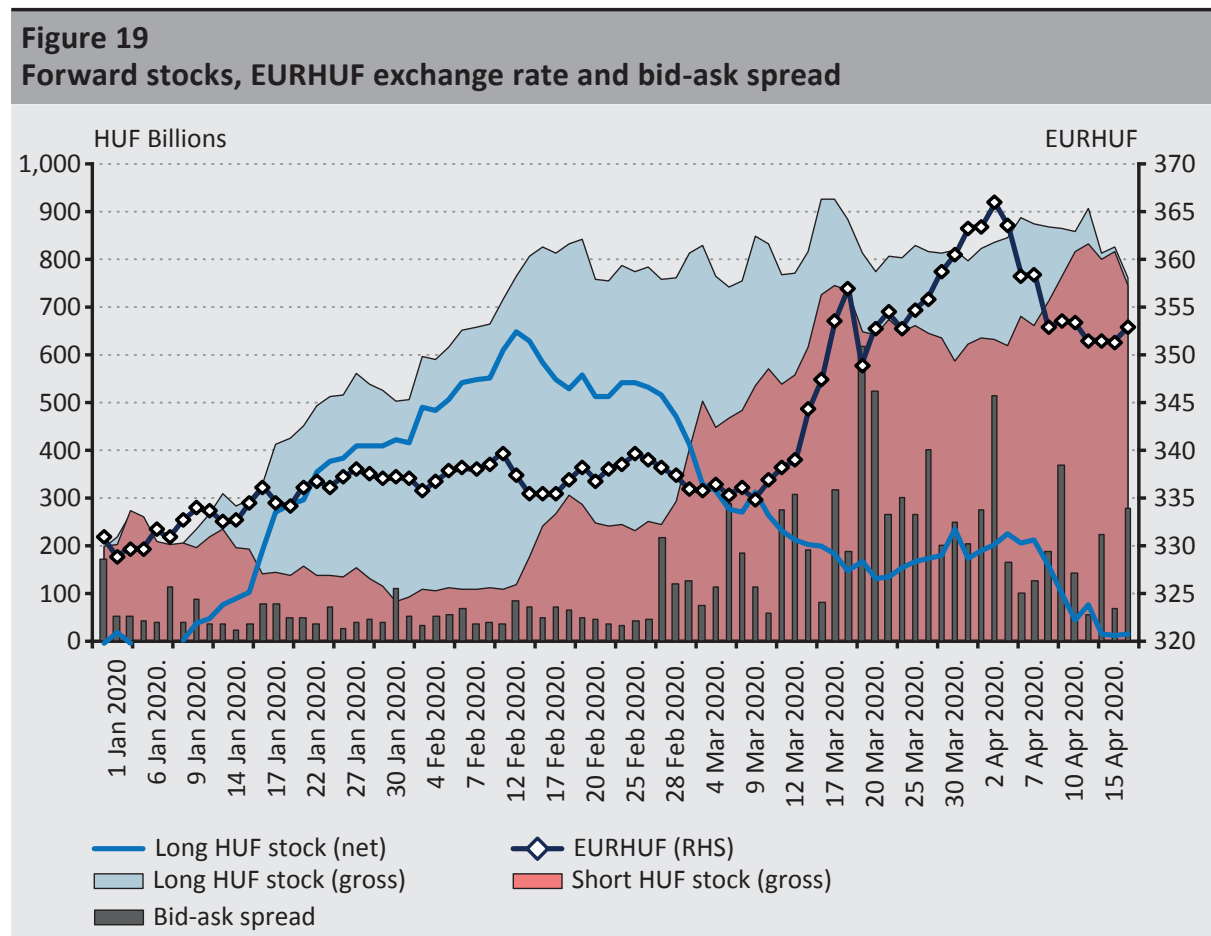

Note: Domestic forward long HUF and short HUF positions cumulated from the beginning of the year (for scaling 1 Jan 2020 = HUF 200 billion). The scale of EURHUF bid-ask spreads adjusted to the chart (their real scale range between 0.1 and 7 forints).

Source: MNB (D01), Bloomberg

On the short HUF side, however, the trading volume exceeded maturities as early as mid-February, and thus we could observe active position openings here. This may have partly been due to precautions related to the expected economic impact of the COVID-19 epidemic, i.e. through these transactions, market participants (mutual funds) could reduce their long HUF exposure in advance if they expected the forint to weaken. Based on the model presented in the previous section, this was less directly related to the daily forint exchange rate changes, and short HUF stocks started to build up partly before the forint weakened more intensively. At the end of February, faltering confidence was already palpable in the US stock market as the VIX index jumped, along with a clear decline in liquidity in the forint spot FX market (Figure 19). Short HUF forward transactions in early March may have been motivated by the depreciation of the FX asset portfolio suffered by international funds. Later, in mid-March, the liquidity needs due to the redemption of mutual fund shares and margin calls may have caused further increases in short HUF forward transactions. 
In early April, market movements moderated and the liquidity in and volatility of the FX market, and within that the FX forward market, began to normalise. Residents' net long HUF forward position decreased further, although at this time the forint strengthened, and thus the traditional positive correlation prevailed. However, based on our model estimates, speculative transactions related to HUF mean reversion remained subdued. The sensitivity of forwards to changes in the EURHUF rate fell to a fraction of the previous values in mid-March and has remained low since then.

\section{Summary}

Our study reviews the most important characteristics of the Hungarian FX forward market, with special regard to the structure of the market and the motivations of the participating market actors. The forint market represents a small part of the global FX market, but its trends and distribution by transaction types are similar and are also characteristic of the domestic segment of the forint market. Forward transactions account for about 10-20 per cent of the forint FX market.

Many of the conclusions of Csávás et al. (2006), who previously comprehensively analysed the domestic forward market, remain valid. In contrast to the spot and currency swap markets, foreign players barely play a role. Due also to regulatory requirements, the Hungarian banking system acts as an intermediary and does not take an open FX position. Non-financial firms (active in international trade) trading in the FX forward market typically take long HUF positions, which (at the aggregate level) corresponds to the natural exposure arising from the domestic net exporter position. The motivation arising from the expectations for the stability of the forint is still a distinct characteristic of non-financial corporate forward transactions. According to bank interviews, a carry trade-type motivation based on interest rate differentials is still present in the market, but its importance has lessened in recent years due to the narrowing of interest rate differentials.

At the same time, our analysis highlights that the most important players in the market are no longer non-financial firms active in international trade, but (similarly to the global scene, e.g. Borio et al. 2017; Patel -Xia 2019; Schrimpf-Sushko 2019) actors in the financial sector. Over the past five to ten years, mutual funds have emerged as the most dominant customer segment within the financial sector in Hungary. The exposures of mutual funds are in many ways similar to those of nonfinancial corporates: they also maintain long HUF positions, by which they partially hedge (one-quarter or one-half of) their FX exposures arising from HUF-financed 
FX assets. Here, too, the motivational element for the stability of the forint can be identified, but to a lesser extent compared to non-financial corporates.

In the case of both sectors - based on our quantitative model - it can be stated that in crisis periods there is a decline in forward trading with a speculative aim to exploit the stability of the forint, and the exchange rate sensitivity of forward stocks diminishes. This also occurred during March of this year during the period of global financial market turbulence caused by the coronavirus. In March 2020, the long HUF FX forward exposures of domestic participants stagnated despite the significant weakening of the forint together with regional currencies: new contracts only covered the maturing stock, and thus, domestic participants did not provide support to the forint exchange rate. At the same time, the stock of short HUF forwards grew rapidly, mostly among mutual funds, initially due to precautionary motives and losses suffered on international FX assets, and later due to liquidity shocks (redemptions of mutual fund shares, margin calls).

Several avenues of further research may help to understand FX market processes more thoroughly. Thanks to the sectoral breakdown of forward stocks, we were able to differentiate the forward market activity of the various players, but the motivations of participants could be much more accurately understood with further disaggregation to individual participants. Our study only focuses on FX forward market exposures. For analysing the FX market as a whole, a joint analysis of other on-balance-sheet and off-balance-sheet FX exposures would be necessary.

\section{References}

Allayannis, G. - Lel, U. - Miller, D.P. (2012): The use of foreign currency derivatives, corporate governance, and firm value around the world. Journal of International Economics, 87(1): pp. 65-79 https://doi.org/10.1016/j.jinteco.2011.12.003

Au, R. - Somefun, K. (2018): Currency risk: full hedging? Or is partial (or no) hedging better? Investors' Corner, BNP Paribas. https://investors-corner.bnpparibas-am.com/investing/ currency-risk-full-hedging/\#_ftnref1. Download date: 23 July 2020.

Barroso, P. - Santa-Clara, P. (2015): Beyond the Carry Trade: Optimal Currency Portfolios. Journal of Financial and Quantitative Analysis. 50(5): 1037-1056. http://doi.org/10.1017/ S0022109015000460

Banai, Á. - Kollarik, A. - Szabó-Solticzky, A. (2013): Az egynapos FX-swap piacok topológiája (Topology of the foreign currency/forint swap market). MNB tanulmányok 108, Magyar Nemzeti Bank. 
BIS (2019a): Triennial Central Bank Survey of Foreign Exchange and Over-the-counter (OTC) Derivatives Markets in 2019. https://www.bis.org/statistics/rpfx19.htm. Download date: 23 July 2020.

BIS (2019b): BIS Quarterly Review December, 2019. www.bis.org/publ/qtrpdf/r_qt1912.html. Download date: 23 July 2020.

Bodnár, K. (2006): A hazai kis- és középvállalatok árfolyamkitettsége, devizahitelezésük pénzügyi stabilitási kockázatai - Egy kérdőives felmérés eredményei (Exchange rate exposure of domestic SMEs, financial stability risks of their foreign exchange borrowing) - Results of a questionnaire survey). MNB tanulmányok 53, Magyar Nemzeti Bank.

Bodnár, K. (2009): Exchange rate exposure of Hungarian enterprises - results of a survey. MNB Occasional Papers 80, Magyar Nemzeti Bank.

Borio, C. - McCauley, R. - McGuire, P. (2017): FX swaps and forwards: missing global debt? BIS Quarterly Review, (September): 37-54. https://papers.ssrn.com/sol3/papers. cfm?abstract_id=3041870. Download date: 23 July 2020.

Csávás, Cs. - Gereben, Á. (2005): Hagyományos és egzotikus opciók a magyar devizapiacon (Vanilla options and exotic options on the Hungarian foreign exchange market). MNB múhelytanulmányok 35, Magyar Nemzeti Bank.

Csávás, Cs. - Kóczán, G. - Varga, L. (2006): A föbb hazai pénzügyi piacok meghatározó szereplői és jellemző kereskedési stratégiái (Key participants and typical trading strategies of the major domestic financial markets). MNB tanulmányok 54, Magyar Nemzeti Bank.

Csávás, Cs. - Szabó, R. (2010): A forint/deviza FX-swap szpredek mozgatórugói a Lehman-csőd utáni időszakban (Determinants of Hungarian forint FX swap spreads after the Lehman crisis). Hitelintézeti Szemle, 9(6): 566-580.

Dempster, A.P. - Laird, N.M. - Rubin, D.B. (1977): Maximum Likelihood from Incomplete Data Via the EM Algorithm. Journal of the Royal Statistical Society: Series B (Methodological), 39(1): 1-22. https://doi.org/10.1111/j.2517-6161.1977.tb01600.x

Endrész, M. - Gyöngyösi, G. - Harasztosi, P. (2012): Currency mismatch and the sub-prime crisis: Firm-level stylised facts from Hungary. MNB Working Papers 2012/8, Magyar Nemzeti Bank.

Endrész, M. - Harasztosi, P. (2014): Corporate Foreign Currency Borrowing and Investment. The Case of Hungary. MNB Working Papers 2014/1, Magyar Nemzeti Bank.

Endrész, M. (2020): The Bank Lending Channel During Financial Turmoil. MNB Working Papers 2020/5, Magyar Nemzeti Bank. 
Fama, E. (1984): Forward and Spot Exchange Rates. Journal of Monetary Economics, 14(3): 319-338. https://doi.org/10.1016/0304-3932(84)90046-1

Gatopoulos, G. - Loubergé, H. (2013): Combined use of foreign debt and currency derivatives under the threat of currency crises: The case of Latin American firms. Journal of International Money and Finance, 35(June): 54-75. https://doi.org/10.1016/j. jimonfin.2013.01.004

Géczy, C.C. - Minton, B.A. - Schrand, C.M. (2007): Taking a view: Corporate speculation, governance, and compensation. The Journal of Finance, 62(5): 2405-2443. http://dx.doi. org/10.1111/j.1540-6261.2007.01279.x

Gereben, Á. - Gyomai, Gy. - Kiss M., N. (2006): Customer order flow, information and liquidity on the Hungarian foreign exchange market. MNB Working Papers 2006/8, Magyar Nemzeti Bank.

Geyer-Klingeberg, J. - Hang, M. - Rathgeber, A.W. (2019): What drives financial hedging? A meta-regression analysis of corporate hedging determinants. International Review of Financial Analysis, 61(January): 203-221. https://doi.org/10.1016/j.irfa.2018.11.006

Guay, W. - Kothari, S.P. (2003): How much do firms hedge with derivatives? Journal of Financial Economics, 70(3): 423-461. https://doi.org/10.1016/S0304-405X(03)00179-X

Harasztosi, P. - Kátay, G. (2020): Currency matching by non-financial corporations. Journal of Banking and Finance, 113(April): 105739. https://doi.org/10.1016/j.jbankfin.2020.105739

Jurek, J.W. (2014): Crash-neutral currency carry trades. Journal of Financial Economics, 113(3): 325-347. https://doi.org/10.1016/j.jfineco.2014.05.004

Kim, S.F. - Chance, D.M. (2018): An empirical analysis of corporate currency risk management policies and practices. Pacific-Basin Finance Journal, 47(February): 109-128. https://doi. org/10.1016/j.pacfin.2017.12.004

Kim, W. - Sung, T. (2005): What makes firms manage FX risk? Emerging Markets Review, 6(3): 263-288. https://doi.org/10.1016/j.ememar.2005.06.002

Kocsis, Z. - Csávás, Cs. - Mák, I. - Pulai, Gy. (2013): Interest rate derivative markets in Hungary between 2009 and 2012 in light of the K14 dataset. MNB Occasional Papers 107, Magyar Nemzeti Bank.

MNB (2020): Commercial Real Estate Market Report, April 2020. Magyar Nemzeti Bank.

Massa, M. - Wang, J. - Zhang, H. (2016): Benchmarking and Currency Risk. Journal of Financial and Quantitative Analysis, 51(2): 629-654. https://doi.org/10.1017/ S0022109016000284 
Melvin, M. - Prins, J. (2015): Equity hedging and exchange rates at the London $4 \mathrm{pm}$ fix. Journal of Financial Markets, 22(January): 50-72. https://doi.org/10.1016/j. finmar.2014.11.001

Mun, K-C. (2016): Hedging bank market risk with futures and forwards. The Quarterly Review of Economics and Finance, 61(August): 112-125. https://doi.org/10.1016/j. qref.2015.11.004

Páles, J. - Kuti, Zs. - Csávás, Cs. (2010): The role of currency swaps in the domestic banking system and the functioning of the swap market during the crisis. MNB Occasional Papers 90, Magyar Nemzeti Bank.

Patel, N. - Xia, D. (2019): Offshore markets drive trading in emerging market currencies. BIS Quarterly Review, December: 53-67.

Pramborg, B. (2005) Foreign exchange risk management by Swedish and Korean nonfinancial firms: A comparative survey, Pacific-Basin Finance Journal, 13(3): 343-366. https://doi. org/10.1016/j.pacfin.2004.04.003

Smith, C.W. - Stulz, R. (1985): The Determinants of Firms' Hedging Policies. Journal of Financial and Quantitative Analysis, 20(4): 391-405. https://doi.org/10.2307/2330757

Schrimpf, A - Sushko, V. (2019): Sizing up global foreign exchange markets. BIS Quarterly Review, December: 21-38.

Vonnák, Dzs. (2018): Why do firms default on their foreign currency loans? The case of Hungary. Journal of International Money and Finance, 86(September): 207-222. https:// doi.org/10.1016/j.jimonfin.2018.05.001

Yu, J. (2013): A sentiment-based explanation of the forward premium puzzle. Journal of Monetary Economics 60(4):474-491. https://doi.org/10.1016/j.jmoneco.2013.04.001 


\section{Appendix}

In the Appendix, information is provided on the background of estimation of the model presented in Section 4 and the robustness of these estimates.

\section{Model specification and data}

The model is estimated with two types of dependent variables, forward transactions (new forward contracts) and the change in the outstanding forward stock, separately for the gross long HUF and gross short HUF forward legs. In the main text the estimates for the latter, changes in the forward stock, are provided. Theoretically, the modelling of the exchange rate effect on both types of dependent variables can be justified, although both contain simplifying assumptions. The difference in assumptions is in how we view the behaviour of market participants in relation to maturing forwards. In the model with forward transactions as the dependent, implicitly, market participants are assumed not to deal with the maturing portfolio. By contrast, in the case of the dependent of changes in the outstanding forward stock, automatic renewal of the maturing stock is the default assumption. In both cases, the logarithmic form seems justified: in the case of forward transactions, the skewness of the distribution is eliminated by taking logs and brought into line with the symmetry in exchange rate changes (the explained variance is also significantly higher as a result than in the case of a linear form). In the case of forward stocks, the advantage of taking the logarithm is that the variance of percentage changes is more homogeneous over time than the variance of linear changes, because the magnitude of (absolute) changes in the portfolio increases in parallel with the increase in the outstanding stock. In the case of forward transactions, due to days without new transactions, the daily transaction volumes are adjusted by adding HUF 1 billion before taking logs (the use of other adjustment factors has no significant qualitative effect on the results). In the Appendix we provide estimates for both linear forms of the forward transaction and the logarithmic form with the aforementioned adjustment.

Regarding the data, we mentioned that the sectoral breakdown in the D01 report is made uncertain by the fact that some of the data-reporting banks in the sample report part of financial clients among the anonymous client group (which are dedicated to retail and corporate clients in the case of other banks). In estimating the model, we considered the most prudent procedure to omit this data from the sample: if, as can be assumed, the customers of these omitted banks behave similarly to the customers of the banks kept in the sample, then such narrowing of the sample has no effect on time-variation in latent parameters interesting for our analysis (due to the percentage form of stock changes also the magnitude of the estimated parameters would remain the same).

Our model specification assumes the changes in the exchange rate to be exogenous, i.e. not affected by changes in the forward stock. Violation of this condition can lead to a problem of simultaneity. The assumption is partly supported by the fact that the volume of domestic trading is significantly smaller compared to the global 
forint market, and therefore any effect is likely to be moderate. However, the possibility of such a reverse effect cannot be ruled out, nor identified at present in the absence of appropriate instruments. ${ }^{15}$

\section{Model estimation}

The unknown parameters of the state-space model described in the main text are the variance parameters $(R, Q)$ and the moments of the $B_{t}$ parameter vector, $\mathrm{E}\left[B_{t}\right]$ and $\operatorname{Var}\left[B_{t}\right]$. The model is estimated by the EM algorithm (Dempster et al. 1977). For the algorithm, starting values were set based on preliminary estimates for the 2003-2005 sample for the total domestic customer base and for non-financial and financial clients, while the 2014-2015 sample was used for mutual funds (transactions before this time were sporadic especially for short HUF forwards in the case of this segment). We used the variance of residuals of fixed-parameter OLS estimates to initialise the variance of the measurement equation $\left(R_{0}\right)$ and changes in OLS parameters estimated based on 200-day rolling windows for the variance of state parameter innovations $\left(Q_{0}\right)$. The initial values $\left(E\left[B_{0}\right]\right)$ of $B_{t}$ were also adjusted to these fixed-parameter OLS estimates, but this initial value is of little significance because we set the uncertainty related to the initial value by orders of magnitude greater than the variance $Q$ according to the following formula $\left(\operatorname{Var}\left[B_{0}\right]=R_{0} X^{\prime} X^{-1}\right)$. This ensures that initial values have a discernible effect on the filtered parameter time series only for a short time (practically 1-2 months). Therefore, the results reported in the main text from 2007 and in the case of mutual funds from 2017 are not affected by the initial value, $B_{0}$. Compared to the initial values $R_{0}, Q_{0}$ we use the $\mathrm{EM}$ algorithm to find more suitable parameter values on the estimation sample.

In the iterative estimation method of the EM algorithm, in each iteration step, the M-step obtains new (maximum likelihood) parameter estimates for the $R, Q$ variance elements based on the filtered moments of $B_{t}$ parameters $\left(E\left[B_{0}\right], \operatorname{Var}\left[B_{0}\right]\right)$ of the previous step. In the E-step, new filtered time series of the $B_{t}$ parameters are generated with the Kalman filter based on the new $R, Q$ estimates, and the likelihood is evaluated. The iteration is continued until the increase in the likelihood exceeds $10^{-6}$. In our case, 2 to 3 steps are usually enough for convergence.

\section{Robustness analysis}

We present two robustness analysis estimates, one concerning the data used and the other concerning the estimation method.

The main text is based on the model where forward stock changes are the dependent variable. Figures 20 and 21 show that models where forward transactions (new forward contracts) are the dependent lead to qualitatively similar results.

\footnotetext{
${ }^{15}$ In the future, intraday transaction data will become available, which may clarify (Granger-type) causality and may also provide an identification tool based on hedging adjustments used in the Melvin - Prins (2016) study. In addition, the strength of the different channels of the exchange rate - forwards relationship can be explored further by a more granular - customer-level - analysis of D01 data.
} 
Figure 20

Exchange rate sensitivity of domestic forward stocks (forward contracts)
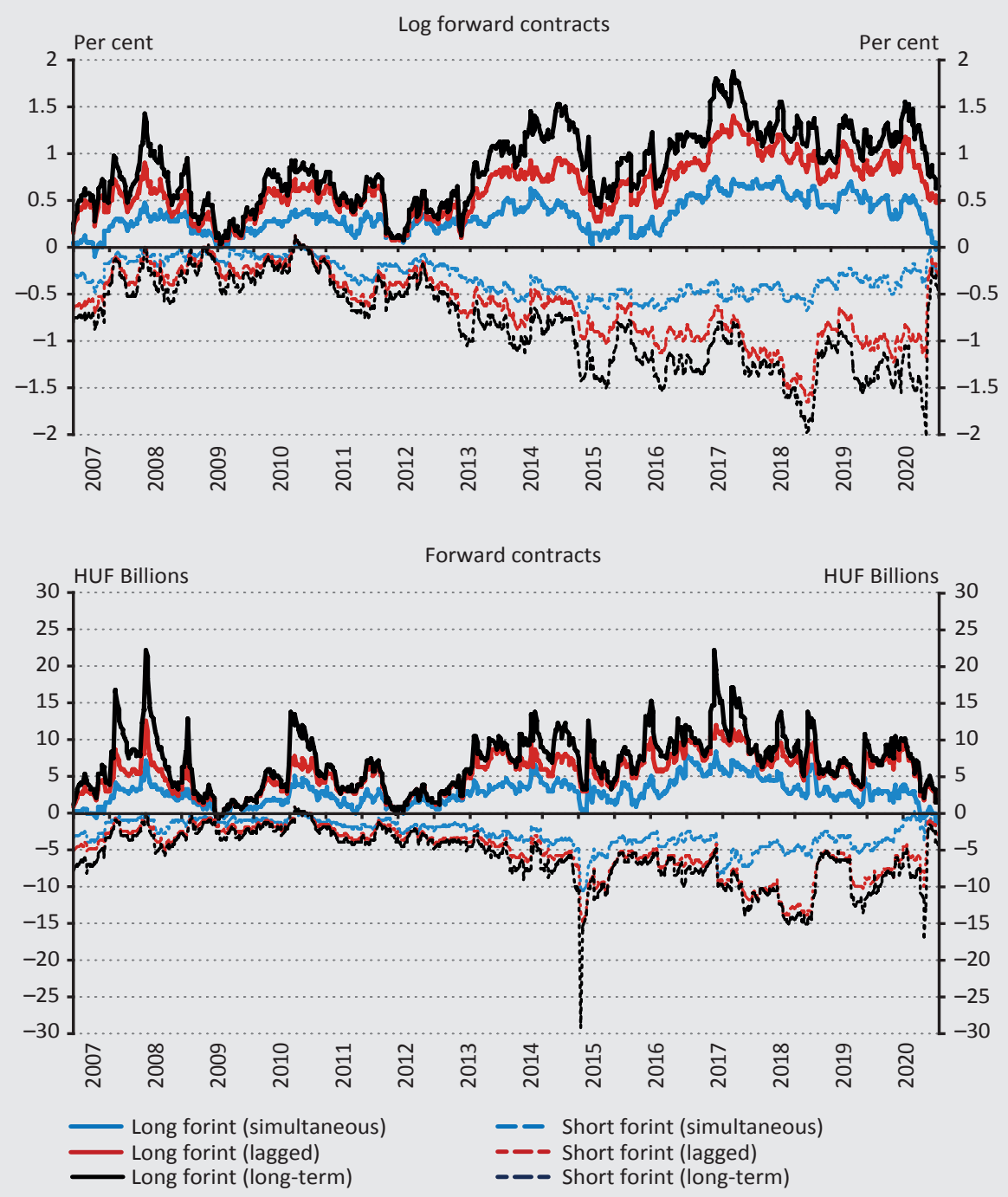

Note: Exchange rate sensitivity time series calculated on the basis of filtered model parameters (top panel: effect of a 1 per cent change in the EURHUF exchange rate on the logarithm of forward transactions, bottom panel: effect of 1 forint change in the exchange rate on forward transactions in HUF billion).

Source: Calculated using MNB (D01) and Bloomberg data 


\section{Figure 21 \\ Exchange rate sensitivity broken down by sectors (forward contracts)}
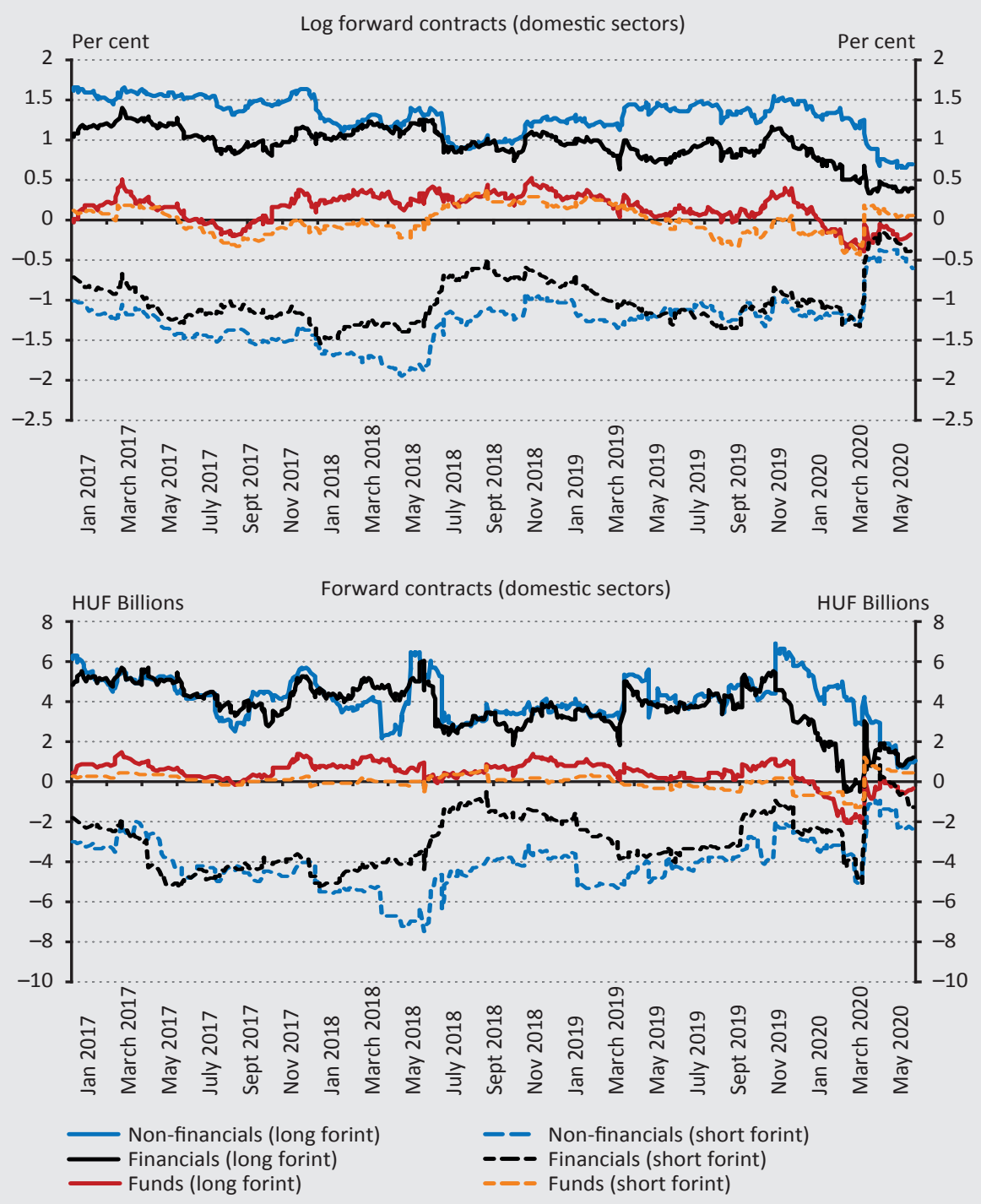

Note: Exchange rate sensitivity time series calculated on the basis of filtered model parameters (top panel: percentage effect of a 1 per cent change in exchange rate on the logarithm of forward transactions, bottom panel: effect of forint exchange rate increase on forward transactions, in HUF billion).

Source: Calculated using MNB (D01) and Bloomberg data 


\section{Figure 22}

Exchange rate sensitivity of domestic forward stocks (alternative methods)

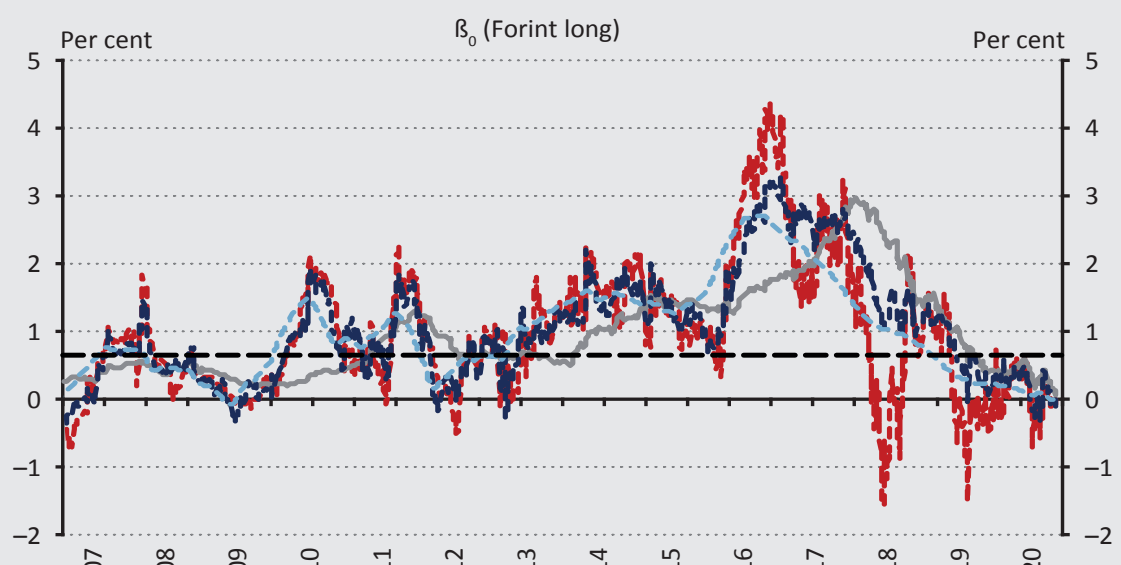

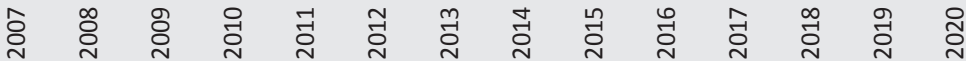

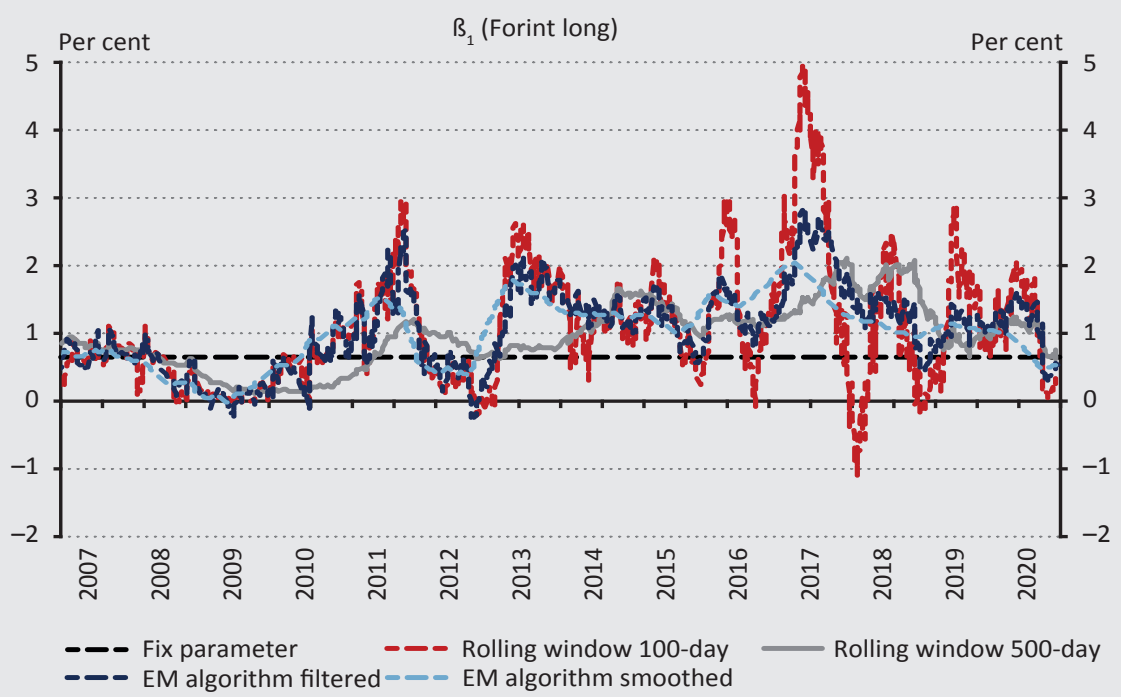




\section{Figure 22 \\ Exchange rate sensitivity of domestic forward stocks (alternative methods)}

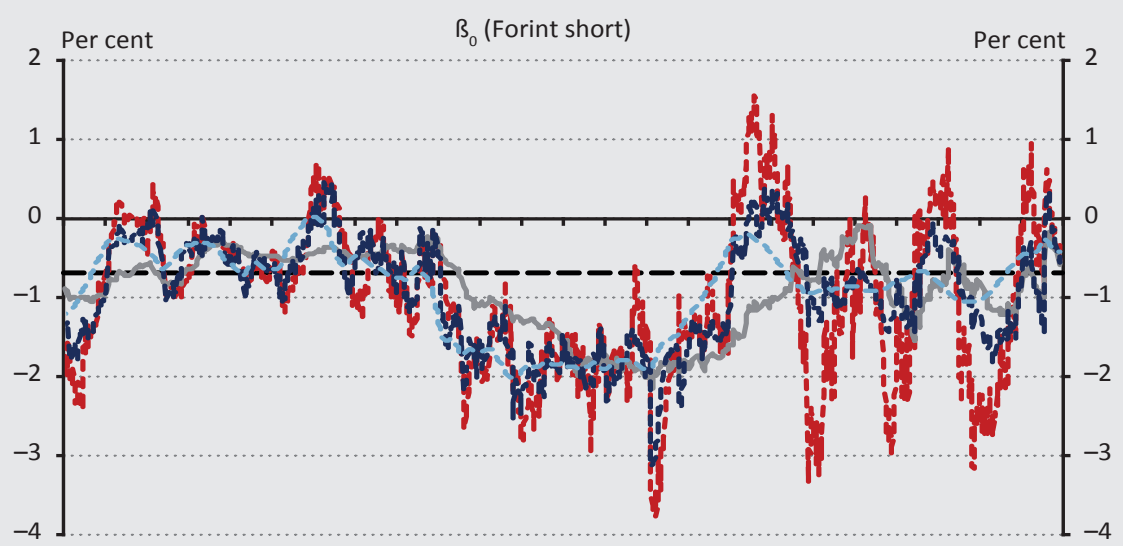

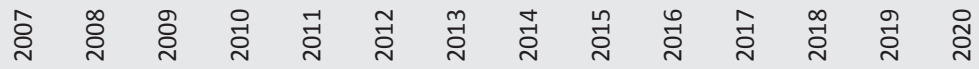

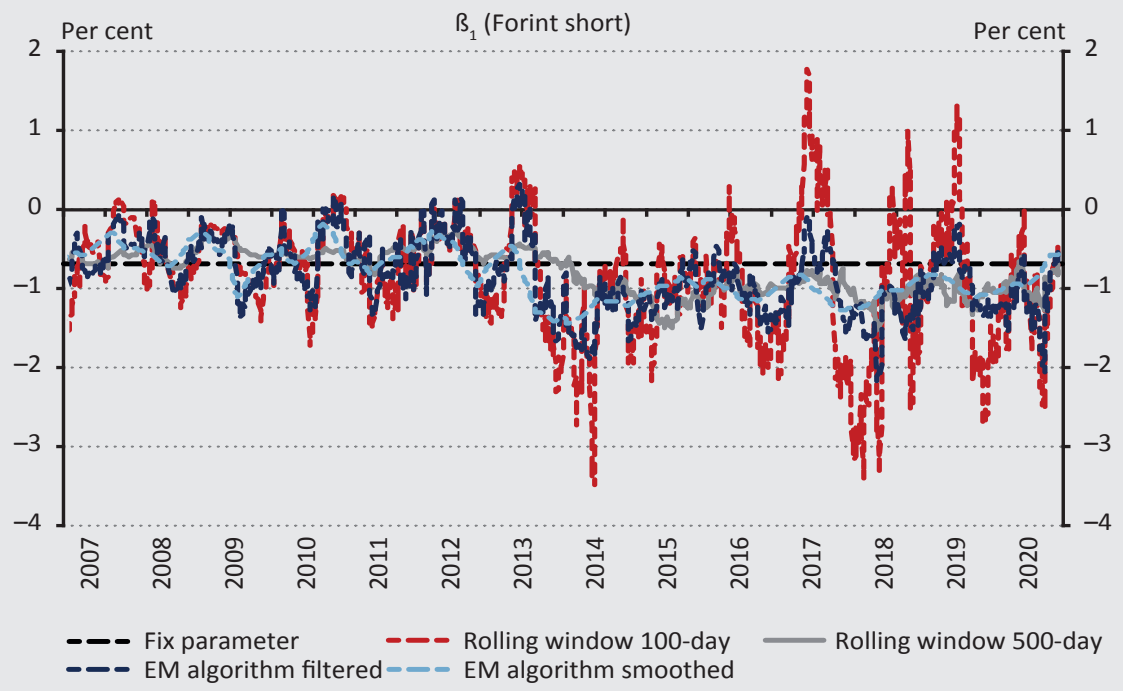

Note: Fix and rolling window parameters estimated by OLS, filtered and smoothed exchange rate sensitivity parameters obtained by the EM algorithm (simultaneous and lagged effects on the forward stock).

Source: Calculated using MNB (D01) and Bloomberg data 
As an alternative to the EM algorithm, we examined how much the $B_{t}$ parameter time series estimated by OLS regression on 100- and 500-day-long rolling windows differed from the filtered parameters we used. Based on Figure 22, the rolling window method also reveals similar trends. The key difference is that the Kalman filter used in the EM algorithm optimally updates the state vector (the expected value of $B_{t}$ ), if the model assumptions are met. However, the advantage of the rolling window method may be that it does not assume a fixed variance and does not contain a constraint for the parameter dynamics. In the current application, the estimates of EM algorithm are more suitable for capturing the current values of the parameters, the rolling window method (due to its stronger retrospective nature) lags the estimates of the EM algorithm. 